\title{
Litter-size-dependent intrauterine growth restriction in sheep
}

\author{
E. Gootwine ${ }^{1 \dagger}$, T.E. Spencer ${ }^{2}$ and F.W. Bazer ${ }^{2}$ \\ ${ }^{1}$ Institute of Animal Science, Agricultural Research Organization, The Volcani Center, PO Box 6, Bet Dagan 50250, Israel; ${ }^{2}$ Department of Animal Science and Center \\ for Animal Biotechnology and Genomics, Texas A\&M University, College Station, TX 77843-2471, USA
}

(Received 9 August 2006; Accepted 14 November 2006)

Regulation of foetal development in sheep depends on interactions between the intrinsic capacity of the foetus for growth and the maternal environment. Lambs born in multi-foetus litters have relatively small placentae with fewer cotelydons, and lower birth weights. Litter-size-dependent intrauterine growth restriction (IUGR) is evident at mid gestation when metabolic needs of the conceptus are moderate, and overnutrition of ewes with multiple foetuses does not promote growth of their foetuses to the size of singletons. Those observations suggest that placental and conceptus growth in multi-foetus pregnancies is reprogrammed at mid gestation by an as yet undefined mechanism to attenuate foetal growth. This may protect the foetus from severe nutritional insult during late gestation, when its daily growth rate is at a maximum. In that way, lambs born in large litters with relatively lower birth weights may not experience the long-term physiological insults that can be observed in small lambs born to undernourished ewes.

Keywords: foetus, intrauterine growth restriction, placenta, sheep, uterus

\section{Introduction}

Foetal growth rate and subsequent birth weight (BWT) of lambs are determined by the genetic background of the foetus which governs its drive for growth, by its paternal genotype which determines placental size, morphology and efficiency of nutrient transfer to the growing foetus, by external environmental conditions such as nutritional status, which affect maternal physiology, and by specific uterine environment-related conditions such as the number of foetuses in the litter (Dickinson et al., 1962; Anthony et al., 2003; Redmer et al., 2004; Safari et al., 2005; Reynolds et al., 2006). Intrauterine growth restriction (IUGR), which leads to the birth of smaller lambs with reduced survival ability, occurs in sheep naturally and can be induced by several means.

\section{Naturally occurring IUGR}

IUGR occurs in ewes carrying multiple foetuses. Increasing prolificacy by genetic and managerial means is associated with an increase in the number of ewes producing large litters. Prolificacy is an important trait in semi-intensive and intensive sheep-production systems. Nevertheless, the economic advantages of high prolificacy are often not fully exploited because pregnancies

\footnotetext{
${ }^{\dagger} E-m a i l:$ gootwine@agri.gov.i
}

with multiple foetuses are associated with IUGR of those foetuses, and lower BWTs and pre- and postnatal survival rates of the lambs (Figure 1) (Hinch et al., 1985; Gama et al., 1991; Fogarty et al., 2000; Holst et al., 2002; Vallet et al., 2002; Christley et al., 2003; Kleemann and Walker, 2005).

Lamb BWT is also affected naturally by maternal age, with lambs born to relatively young ewes (first and second parities), and to relatively old ewes (ninth and above parities), being smaller than lambs born to ewes in their third to the eighth parities (Al-Shorepy, 2001; Gootwine et al., 2006b). Seasonality also affects lambs' BWT, those born in the summer and autumn being smaller than those born in the winter and spring (McCoard et al., 1996; Al-Shorepy and Notter, 1998; Gootwine and Rozov, 2006). The seasonal effect on BWT is due to both a direct seasonal effect on foetal growth, possibly mediated through variations in melatonin secretion, and an indirect seasonal effect on gestation length (Gootwine and Rozov, 2006).

Altitude is another natural factor that affects BWT of lambs, with those born to ewes at high altitude and subjected to hypobaric hypoxia being lighter than those born to ewes at low altitude (Parraguez et al., 2005). Thus, foetal growth is affected by a number of intrinsic and extrinsic factors that can negatively impact on lamb BWT. 


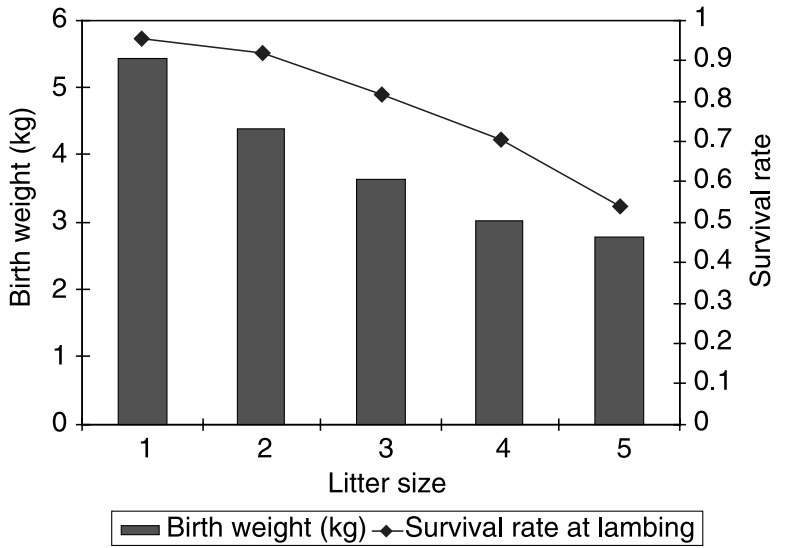

Figure 1 Birth weights and perinatal survival rates for lambs $(n=4781)$ born to Afec-Assaf ewes (Volcani Center, Israel), according to litter size (after Gootwine and Rozov (2006)).

\section{Experimental IUGR}

IUGR can be induced in ewes by various means, including manipulation of maternal nutrition, administration of glucocorticoids, artificial restriction of placental size, creation of uteroplacental embolisms, and exposure of pregnant ewes to extreme environmental conditions, such as high temperature and low oxygen pressure (McMillen et al., 2001; Regnault et al., 2002; Redmer et al., 2004; Fowden et al., 2006c; Wallace et al., 2006). Interestingly, such simple practices as shearing ewes during mid or late pregnancy can increase lamb BWTs (Symonds et al., 1992; Revell et al., 2000; Kenyon et al., 2002). In most cases, changes in foetal weight due to either natural or induced IUGR are associated with a reduction in placental size and potentially, functionality.

\section{The enigma of litter-size-dependent IUGR}

The literature clearly indicates that foetal growth is regulated by the placental transport of nutrients, oxygen and water to the foetus from the maternal compartment through the uteroplacental complex (Regnault et al., 2005; Fowden et al., 2006c). Therefore, litter-size-dependent IUGR may result from failure of the uteroplacental complex fully to support growth of the multiple foetuses within the same uterus. Indeed, available evidence from studies of both sheep (Edwards and McMillen, 2002; Gardner et al., 2004; MacLaughlin et al., 2005) and humans (De Boo and Harding, 2006) suggests that reduced BWTs of individual lambs born in litters with more than one lamb have features in common with IUGR in lambs resulting from undernutrition, such as reduction in uterine blood flow per foetus and lower metabolite concentration in the maternal and foetal circulations. However, as ewes can clearly maintain a litter to term for which total weight approaches three times that of a normal single lamb (Dickinson et al., 1962), it is unclear why the individual BWTs of lambs born as twins or triplets are lower than those of lambs born as singletons. This observation suggests that sheep foetuses that gestate in multi-foetal pregnancies have unique features that make their growth trajectory different from that of singletons.

Foetal growth and development have been investigated mainly in ewes pregnant with singleton lambs. Information on foetal development in pregnancies with multiple foetuses is therefore relatively limited. The present review focuses on foetal growth in ewes with multiple foetuses during pregnancy, aiming to better understand the nature of litter-size-dependent IUGR, a biological phenomenon that has major economic implications in sheep-production systems, as well as in other livestock-producing enterprises such as pig production (Wu et al., 2006).

\section{General description of foetal and placental growth during pregnancy in sheep}

\section{Uterine anatomy}

In sheep, the uterine endometrium has two distinct areas: aglandular caruncular and glandular intercaruncular. The intercaruncular area contains large numbers of endometrial glands that synthesise and secrete a complex array of proteins termed histotroph, which include enzymes, growth factors, cytokines, lymphokines, hormones, transport proteins and other substances (Wimsatt, 1950; Roberts and Bazer, 1988). During pregnancy, histotroph is transported via placental areolae from the uterine glands into the foetal circulation and then much is cleared via the kidney and urachus into the allantoic fluids which serves as a nutrient reservoir to nourish the growing conceptus (the foetus and its extraembryonic membranes) (Renegar et al., 1982). Histotroph is particularly important during the early stages of pregnancy (Spencer and Bazer, 2004), before hematotrophic nutrition is established. Hematotrophic nutrition relies on the exchange of nutrients and gases between vasculature of the maternal uterus and placenta of the conceptus (Gray et al., 2001). The relative contribution of histotrophic and hematotrophic nutrition to conceptus development during the late stages of pregnancy is not established. However, it can be assumed that while placental transport of $\mathrm{O}_{2}$, amino acids, glucose and micronutrients is mostly hematotrophic, delivery of key regulatory molecules such as vitamins, hormones and growth factors is mediated by uptake of histotroph from uterine glands via the placental areolae.

The aglandular areas of the endometrium are termed caruncles. On average, the sheep uterus has about 100 caruncles, with numbers ranging from 50 to 150 per uterus (Alexander, 1964b). Caruncles are features of the neonatal uterus of lambs (Wiley et al., 1987) and their number in primiparous ewes is related to uterine size (Figure 2). Little information is available on what initiates placentome formation and how it develops during gestation.

\section{Placental formation}

Sheep have a non-invasive, synepitheliochorial-type placenta (Björkman, 1970). Following implantation, the 


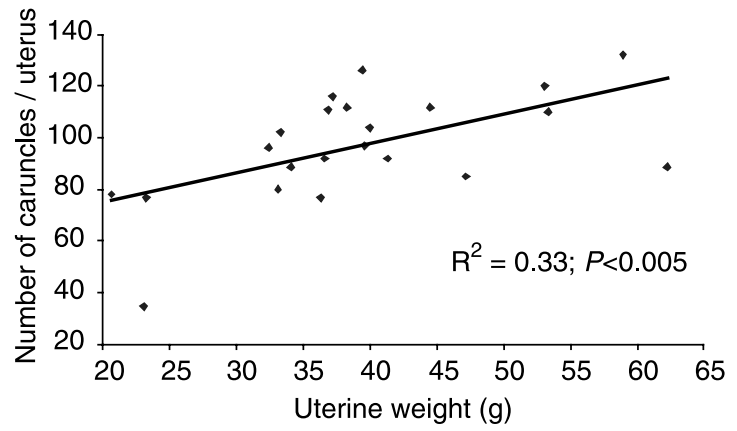

Figure 2 Association between number of caruncles and uterine weight in primiparous crossbred ewes ( $n=22$, Texas A\&M University, Texas, USA).

chorioallantoic membranes of the conceptus elongate and through an unknown mechanism, form cotyledons that interdigitate with the caruncles to form placentomes (Wimsatt, 1950), where the placenta becomes syndesmochorial in nature. Placentomes are structures containing the uteroplacental complexes responsible for exchange of gases and micronutrients. The placenta is an autocrine, paracrine and endocrine organ that synthesises and secretes a broad range of steroid and peptide hormones which regulate foetal development, and directs maternal physiology to support this process (Anthony et al., 1998; Gootwine, 2004; Murphy et al., 2006).

Placenta of a single foetus appears to be programmed to involve only about $70 \%$ of the total available caruncles in placentome formation. Variation among ewes in the numbers of caruncles on the endometrial surface may account for the variation in placentome numbers (Alexander, 1964a). On average, placentae of singleton conceptuses have 70 placentomes that vary in size and morphological appearance (Ward et al., 2006).

\section{Foetal and placental growth}

Average gestation length in sheep is 147 days. Throughout gestation, growth patterns for the placenta and foetus differ, as main placental growth takes place before the period of rapid foetal growth (Figure 3). Foetal growth in sheep is best described by the Gompertz equation (Robinson et al., 1977). During the first half of gestation, foetal growth is slow: by the end of that period the foetus has achieved only about $10 \%$ of its BWT. During the second half of pregnancy, foetal growth is exponential and near the time of parturition, daily foetal weight gain ranges from 70 to $150 \mathrm{~g} /$ day, which is reflected directly in the BWT of the foetus (Figures 3 and 4).

In contrast to the pattern of foetal growth, placental development, in terms of weight, length and surface area, increases progressively from the peri-implantation period (16 to 30 days of gestation) to its maximum size at 75 to 80 days of pregnancy. Then, indices of placental size either stabilise or decline slightly near the end of the pregnancy (Figure 3). Placental weight and foetal weight are poorly

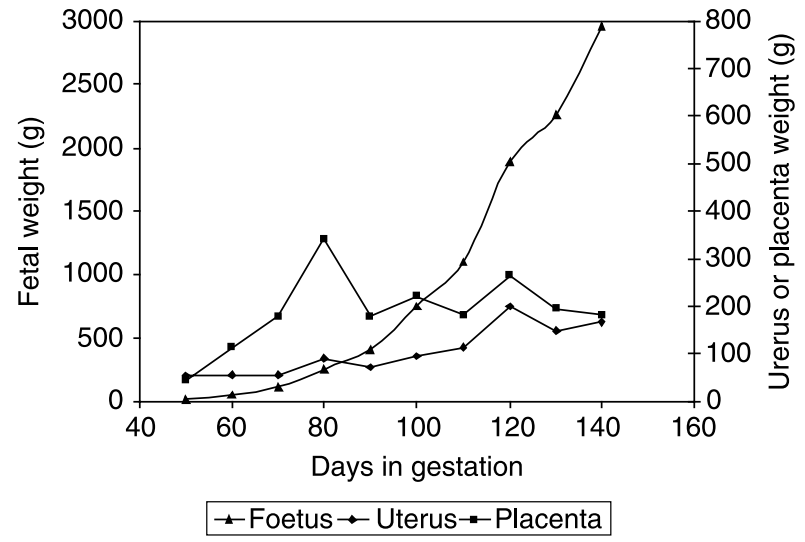

Figure 3 Growth of the foetus and placenta during pregnancy in Florida Native ewes ( $n=4$ per age group; FW Bazer, TE Spencer, WW Thatcher and DC Barron, unpublished results).

correlated during early gestation; however, they are highly correlated late in gestation and at parturition (Naaktgeboren and Stegeman, 1969; Greenwood et al., 2000).

Placentome restructuring during pregnancy

During the last two-thirds of gestation, both the maternal (caruncular) and foetal (cotyledonary) portions of the placentome undergo structural changes which include vascular development and angiogenesis. Angiogenesis and vasodilation within placentomes are mediated by various angiogenic factors, including vascular endothelial growth factor (VEGF) and nitric oxide (NO). While the cotyledonary capillary beds grow primarily by branching (angiogenesis) to provide a very high density of small capillaries, the caruncular capillary beds grow mainly by increasing the size of the capillaries (vasodilation), with smaller increases in capillary density (Reynolds and Redmer, 2001; Reynolds et al., 2005a and 2005b).

Placental weight may decrease slightly during the second half of gestation; however, the amount of DNA in the placentomes changes little during that period, suggesting that the reduction in placental weight is due

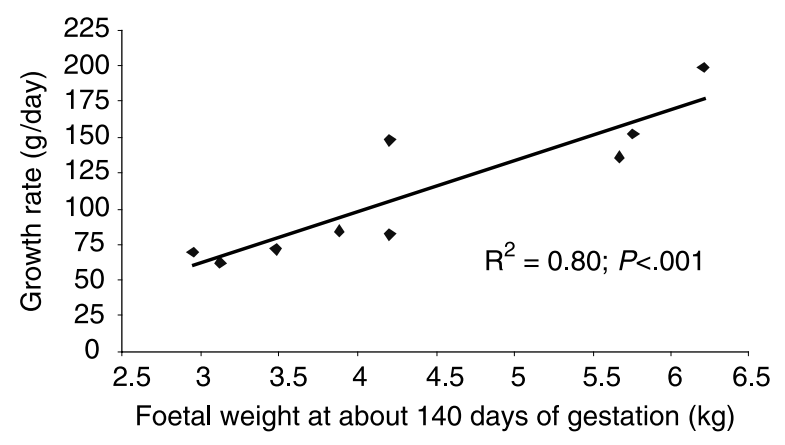

Figure 4 Association between foetal weight at about 140 days of gestation and its daily growth rate in different experiments (FW Bazer, TE Spencer, WW Thatcher and DC Barron, unpublished results form study on Florida Native ewes; Rattray et al., 1974; Robinson et al., 1977; Sinclair et al., 1998; Corner et al., 2006; Gootwine and Rozov, 2006). 
mainly to structural modifications and/or the tissues' state of hydration, rather than changes in cell number (Ott et al., 1997; Reynolds et al., 2005a).

\section{Uterine blood flow}

Increases in vascularisation of the placentomes during gestation are followed by increases in uterine blood flow to accommodate the requirements for nutrients and gases that support rapid foetal growth (Reynolds et al., 2006). Thus, while the rate of total uterine blood flow is about $0.4 \mathrm{l} / \mathrm{min}$ at 71 days of pregnancy, it increases some threefold by day 130 of gestation, to about $1.2 \mathrm{l} / \mathrm{min}$. Similarly, total umbilical blood flow increases throughout gestation (Reynolds et al., 2006). It is estimated that by the end of gestation, $20 \%$ of the maternal cardiac output is targeted to the uterus to provide nutrients and oxygen to support the growing conceptus, primarily the foetus.

\section{Placental oxygen and glucose consumption}

The placenta has high metabolic demands for its own growth and for the endocrine and transport functions that support the growing foetus. The placenta consumes approximately two-thirds of the oxygen and one-half of the glucose transferred from the uterine circulation to the conceptus (Harding and Johnston, 1995). Part of the placental glucose is converted to fructose in the placenta, which is an important form of stored energy for the foetus (Moores et al., 1993).

In general, the size of the placenta is correlated with its glucose and amino acid transfer capacity, which is determined by transporter abundance (reviewed by Regnault et al. (2005) and Fowden et al. (2006c)). Interruptions in the normal placental growth trajectory caused by carunclectomy (Owens, et al., 1987), heat stress (Thureen et al., 1992), nutrition manipulation (Wallace et al., 2002), or prolonged hypoglycemia (Carver and Hay, 1995) may either increase or decrease glucose and amino acid transporter abundance and hence, the efficiency of placental nutrient-transfer capacity.

\section{Roles of the conceptus and ewe in foetal growth}

The understanding that both the foetus and ewe determine the foetal growth trajectory comes from crossbreeding trials and embryo-transfer experiments between large and small breeds, as well as from within-breed genetic analyses of source BWT variations.

\section{Between-breed analyses}

Lambs of large breeds have higher BWTs than those of small breeds (Donald and Russell, 1970), reflecting genetic differences in foetal growth, maternal uterine functions, uteroplacental development, and likely a combination of all of these factors. Results of embryo-transfer experiments demonstrated that Welsh Mountain (small breed) lambs gestated in Lincoln (large breed) surrogate ewes are heavier at birth than Welsh Mountain lambs born to Welsh Mountain ewes. In addition, Lincoln lambs born to Welsh
Mountain ewes had lower BWTs than Lincoln lambs born to Lincoln ewes (Dickinson et al., 1962). Thus, there is an interaction between foetal and maternal factors which determines the extent of foetal growth, and the maternal environment does not, in and of itself, determine or support maximal foetal growth.

Similar conclusions were reached following experiments in which Romanov embryos (small breed with average ewes' body weight of $45 \mathrm{~kg}$ ) were transferred into Columbia ewes (large breed with average ewe weight of $104 \mathrm{~kg}$ ) (Scheaffer et al., 2004). At 130 days of gestation, Romanov foetuses gestated in Columbia ewes were 22\% heavier than control Romanov foetuses gestated in Romanov ewes. The remarkable plasticity of foetal and placental growth and the ability of the foetus to respond to permissive or restrictive aspects of the maternal environment have also been observed following embryo-transfer experiments involving small and large breeds of horses (Allen et al., 2002), pigs (Wilson et al., 1998) and cattle (Ferrell, 1991).

Maternal genetic effects on foetal growth were also demonstrated in crossbreeding experiments between large and small breeds. For example, crossbreeding between Assaf (large) and Booroola Merino (small) breeds (Gootwine et al., 1993) increased BWTs of lambs in response to contributions of the large breed to the foetal genome, and to contributions of the maternal genome. A difference in BWT of about $0.5 \mathrm{~kg}$ resulted when lambs of similar genetic backgrounds were gestated in ewes with different genetic backgrounds in terms of body size.

\section{Within-breed genetic analysis}

BWT can be considered both a foetal-related trait (direct effect) and a maternal-related trait (maternal effect). Within-breed genetic variation in BWT has been estimated for several breeds of sheep (see reviews by Fogarty (1995) and Safari et al. (2005)). Both direct and maternal effects have been found to have moderate heritability values and in most cases, the genetic correlation between direct and maternal effects was negative (Table 1). These findings suggest that some genetic and physiological factors that enhance foetal growth also have negative effects later in life on the maternal ability to support foetal growth. Antagonistic or negative genetic correlations between direct and maternal effects on BWT have also been reported for beef cattle and pigs (Robinson, 1981; Meyer, 1992).

\section{Genetic imprinting and foetal and placental growth}

An antagonistic relationship between the expression of genes supporting foetal growth and those supporting placental development and function is observed in imprinted genes. Genomic imprinting (Tilghman, 1999) is an epigenetic phenomenon in which the expression of certain genes is dependent on whether they are inherited from the mother or father. A substantial proportion of known imprinted genes are involved in the control of foetal growth and placental development (Reik and Walter, 2001). In general, paternally expressed genes enhance placental growth, while 
Table 1 Estimates of direct heritability $\left(h_{a}^{2}\right)$, maternal heritability $\left(h_{m}^{2}\right)$ and coefficients of correlation between direct and maternal genetic effects $\left(r_{a m}\right)$ for birth weight of lambs born to ewes with different genotypes

\begin{tabular}{|c|c|c|c|c|}
\hline Breed of ewe/age $^{\dagger}$ & $h_{\mathrm{a}}^{2}$ & $h_{\mathrm{m}}^{2}$ & $r_{\mathrm{am}}$ & Reference \\
\hline Afrino sheep & 0.22 & 0.09 & & Snyman et al., 1995 \\
\hline Arab local sheep & 0.42 & 0.33 & -0.6 & Al-Shorepy, 2001 \\
\hline Baluchi & 0.17 & 0.10 & 0.17 & Yazdi et al., 1997 \\
\hline Columbia & 0.27 & 0.25 & -0.05 & Hanford et al., 2002 \\
\hline Columbia & 0.18 & 0.24 & -0.20 & Bromley et al., 2000 \\
\hline Columbia/1y & 0.08 & 0.00 & -0.99 & Okut et al., 1999 \\
\hline Columbia/2-3y & 0.25 & 0.27 & -0.07 & Okut et al., 1999 \\
\hline Columbia/>3y & 0.23 & 0.26 & -0.39 & Okut et al., 1999 \\
\hline Crossbreeds & 0.09 & 0.17 & 0.01 & Mousa et al., 1999 \\
\hline Mixed population & 0.19 to 0.34 & 0.3 to 0.65 & -0.74 to -0.18 & Burfening and Kress, 1993 \\
\hline Hampshire & 0.39 & 0.22 & -0.56 & Tosh and Kemp, 1994 \\
\hline Polled Dorset & 0.12 & 0.31 & -0.35 & Tosh and Kemp, 1994 \\
\hline Polypay & 0.16 & 0.21 & 0.12 & Bromley et al., 2000 \\
\hline Polypay/1y & 0.46 & 0.25 & -0.29 & Okut et al., 1999 \\
\hline Polypay/2-3y & 0.14 & 0.22 & -0.17 & Okut et al., 1999 \\
\hline Polypay/>3y & 0.14 & 0.22 & 0.33 & Okut et al., 1999 \\
\hline Rambouillet & 0.19 & 0.18 & -0.09 & Bromley et al., 2000 \\
\hline Rambouillet/1y & 0.39 & 0.29 & -0.12 & Okut et al., 1999 \\
\hline Rambouillet/2-3y & 0.18 & 0.23 & 0.08 & Okut et al., 1999 \\
\hline Rambouillet/>3y & 0.22 & 0.17 & 0.16 & Okut et al., 1999 \\
\hline Romanov & 0.04 & 0.22 & -0.99 & Maria et al., 1993 \\
\hline Romanov & 0.07 & 0.13 & -0.13 & Tosh and Kemp, 1994 \\
\hline Swedish Finewool & 0.07 & 0.30 & 0.11 & Nasholm and Danell, 1996 \\
\hline Scottish Blackface & 0.14 & 0.28 & -0.51 & Bishop and Mackenzie, 2001 \\
\hline Soay & 0.11 & 0.16 & -0.41 & Wilson et al., 2005 \\
\hline Targee/1y & 0.29 & 0.02 & 0.99 & Okut et al., 1999 \\
\hline Targee/2-3y & 0.35 & 0.18 & 0.19 & Okut et al., 1999 \\
\hline Targee/3y & 0.35 & 0.22 & -0.07 & Okut et al., 1999 \\
\hline Targee & 0.22 & 0.19 & 0.08 & Bromley et al., 2000 \\
\hline Targee & 0.25 & 0.20 & 0.09 & Hanford et al., 2003 \\
\hline
\end{tabular}

${ }^{\dagger}$ Age of ewes, where known $(y=$ year).

maternally expressed genes reduce placental size and its nutrient-transport ability (Isles and Holland, 2005; Angiolini et al., 2006; Cattanach et al., 2006; Fowden et al., 2006b).

Most of the research on genomic imprinting has been conducted with mice. Imprinting of genes controlling foetal and placental growth has been suggested to occur in sheep as well following the observation that parthenogenetic development of embryos is associated with retardation of foetal growth (Feil et al., 1998; Hagemann et al., 1998). A detailed study on the genomic imprinting status of the IGF2 gene in sheep (McLaren and Montgomery, 1999) revealed that ovine IGF2 is imprinted in the foetal kidney, liver, and spleen but not in the brain. As in humans, but not in mice, ovine IGF2 imprinting in the liver is switched off postnatally and in the adult sheep liver IGF2 has a bi-alleleic mode of expression.

As the interaction between paternally and maternally expressed genes is still under investigation, it is not yet clear how the expression of imprinted genes in the control of foetal growth-drive and placental structure and function is associated with the genetic response to selection for BWT. Nevertheless, in multi-foetal pregnancies, polymorphism in genetic imprinted genes can contribute to within-litter-size variations in BWT (Gootwine et al., 2006c), even when all foetuses have a similar genetic make-up.

Major genes affecting BWT

Foetal growth rate and BWT of lambs are quantitative traits that are controlled by many loci with small effects of each locus on variations in the trait. Recently, the $F e c B$ gene which controls ovulation rate in ewes (Piper et al., 1985) was found to have a major effect on BWT of lambs (Gootwine et al., 2006b). When the Booroola mutation was carried by either the lamb or the ewe, it negatively affected the lambs' BWT. Differences in foetal growth rates between carriers and noncarriers of the Booroola mutation were detected as early as day 40 of gestation (Smith et al., 1993 and 1996).

\section{Foetal and placental growth in pregnancies with multiple conceptuses}

BWT and body composition Individual foetuses in pregnancies with multiple conceptuses have lower BWTs than a lamb gestated as a singleton. On average, BWTs for lambs born as twins, triplets and quadruplets are $0.83,0.70$ and 0.63 that of 
singleton lambs, respectively (Gootwine, 2005). Furthermore, in a study in which average BWTs of singletons, twins, triplets and quadruplets were 5.4, 4.4, 3.6 and $3.1 \mathrm{~kg}$, respectively, gestation lengths for ewes carrying twins, triplets and quadruplets were reduced by an average of $0.5,1.0$ and 1.5 days, respectively, compared with that for ewes carrying a single foetus (Gootwine and Rozov, 2006). Thus, only a minor part of the reduction in BWT of foetuses born in litters can be attributed to reduced gestation length, as foetal growth rate during the last part of the gestation is estimated to be $101 \mathrm{~g} /$ day for twins compared with $199 \mathrm{~g} /$ day for singletons (Rattray et al., 1974).

The average increase in total litter weight for twins in sheep is about 1.6 times that for a single lamb (Freetly and Leymaster, 2004). As illustrated in Figure 5, divergence in foetal weight gain as the number of foetuses increases can be detected before day 100 of gestation (Winters and Feuffel, 1936; Naaktgeboren and Stegeman, 1969; Rattray et al., 1974), when placental size is almost maximal but overall foetal mass is less than one-half that of a singleton foetus.

The degree of litter-size-dependent IUGR - the rate at which BWT declines as litter size increases, was found to be highly variable among sheep populations (Gootwine, 2005). The significance of that variability, which may result from both genetic and environmental factors, can be demonstrated by calculating the expected BWT of triplets in a population of ewes in which the average BWT of singleton lambs is $4.5 \mathrm{~kg}$. Using the extreme values for littersize-dependent IUGR, BWT of individual lambs born as triplets can vary between 1.7 and $3.6 \mathrm{~kg}$, that is 0.38 to 0.80 of the BWT of lambs born as singletons, respectively.

The reduction in BWT of individual lambs as litter size increases is closely associated with a reduction in total energy and total protein content in the lamb's body (Rattray et al., 1974). Lower foetal weights in pregnancies with twin lambs is associated with reduced weights of muscle and, for some muscles, differences were found between singleton and twin lambs in fiber number and crosssectional area (McCoard et al., 1997 and 2000).
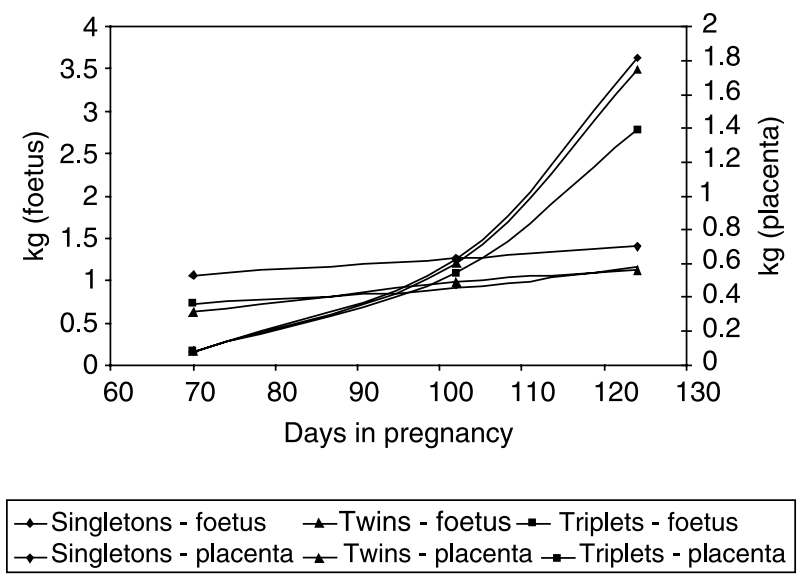

Figure 5 Foetal and placental growth in ewes with single, twin and triplet lambs (after Rattray et al. (1974)).
Within-litter variation in BWT

Sibling foetuses may differ in their BWTs. Within-litter variability in BWT increases with litter size (Gootwine et al., 2006c) (Table 2). The degree of within-litter variability in lamb BWT may be defined by the maternal uterine environment or by segregation of genes among sibling foetuses that affect placental development and function, as well as foetal growth. Interestingly, a low but significant estimate of heritability was found for within-litter variation in BWT in pigs, suggesting that this trait can be improved in those animals by genetic selection (Damgaard et al., 2003). In contrast, within-litter variation in lamb BWT has a very low heritability value, suggesting that most of that variation is non-genetic in nature (Gootwine et al., 2006c).

\section{Placentome number and size}

Increasing the number of foetuses in a litter leads to higher occupancy of uterine caruncles and greater aggregate placental weight. However, there is an overall reduction in placental size and fewer placentomes per conceptus. Placentome number per conceptus decreases from about 70 for singletons to about 40 in twins, and 28 and 22 in triplets and quadruplets, respectively (Alexander, 1964b; Rhind et al., 1980; Greenwood et al., 2000; Kaulfuss et al., 2000; Pant et al., 2003; Dwyer et al., 2005; Grazul-Bilska et al., 2006). In studies in which total placentome numbers were relatively high, maximum occupancy of caruncles was observed in pregnancies with twins, while for litters in which total placentome numbers were relatively low, maximal occupancy of caruncles was found to be highest in ewes with triplets (Figure 6).

The decrease in placentome number per foetus with increases in litter size is associated with an increase in the average size of the placentomes (Figure 7), followed by an increase in the vascular density of cotyledons (Virrenga et al., 2004). However, despite the increase in placentome size, placentae of twins and triplets do not achieve the total placentome mass of single conceptuses.

Manifestations of compensatory growth of the placenta when the number of placentomes is reduced have been demonstrated using three experimental models.

\section{Model 1: uterine ligation}

The ligation of one uterine horn and removal of the ipsilateral ovary restricts conceptus development throughout pregnancy by reducing the endometrial surface available for placental development (Bazer et al., 1979). The average number of caruncles occupied by the placenta of a single foetus was reduced by $47 \%$ in ewes with ligated uterine horns, to a level characteristic of placentome numbers for each conceptus in a litter of quadruplets (Caton et al., $1984)$ or by $22 \%$, to the level characteristic of a pregnancy with twins (0tt et al., 1997). However, average foetal and placental weights in ewes with singletons did not differ at 140 days of gestation between control ewes and those with a ligated uterine horn. 
Table 2 Least-squares means \pm s.e. for birth weight (BWT) of Afec-Assaf lambs, within-litter coefficient of variation (CV) of BWT, and within-litter range of BWTs according to litter size (Gootwine et al., 2006C)

BTW (mean \pm s.e.) of the heaviest and lightest lambs as proportion of total weight of the litter

\begin{tabular}{|c|c|c|c|c|c|}
\hline \multirow[b]{2}{*}{ Litter size } & \multirow[b]{2}{*}{ No. of litters } & \multirow[b]{2}{*}{ BTW $(\mathrm{kg})$} & \multirow[b]{2}{*}{$\mathrm{CV}$} & \multirow[b]{2}{*}{ Heavy } & \multirow[b]{2}{*}{ Light } \\
\hline & & & & & \\
\hline 2 & 1292 & $4.5^{a} \pm 0.02$ & $0.100 \pm 0.004$ & $0.54 \pm 0.03$ & $0.46 \pm 0.03$ \\
\hline 3 & 555 & $3.7^{b} \pm 0.03$ & $0.160 \pm 0.006$ & $0.38 \pm 0.03$ & $0.28 \pm 0.03$ \\
\hline 4 & 140 & $3.0^{c} \pm 0.02$ & $0.180 \pm 0.099$ & $0.30 \pm 0.03$ & $0.20 \pm 0.03$ \\
\hline
\end{tabular}

a,b,c Within a column, means with different letters differ significantly $(P<0.05)$.

Model 2: carunclectomy

The surgical removal of caruncles from the uteri of nonpregnant ewes results in fewer placentomes during pregnancy (Alexander, 1964a). This experimental model has been used to study the foetus' physiological adaptation to placental restriction (Robinson et al., 1979; Butler et al., 2002; Danielson et al., 2005). However, the reduction in placentome numbers by carunclectomy did not affect placental or foetal size, even when 67 caruncles were removed. These results again demonstrate the amazing capacity for compensatory development of the placentomes to support conceptus development in ewes.

\section{Model 3: foetectomy}

Unlike the situation in rabbits, rats and monkeys (Taylor et al., 1983; Albrecht and Pope, 1985), removal of the foetus from the pregnant uterus of ewes results in degeneration or expulsion of the placenta. This is attributed to a lack of adequate circulation in which the foetal heart is the pump required to sustain perfusion of the entire conceptus with blood. In an experiment where one of two foetuses in the pregnant uterus was removed surgically at day 50 of pregnancy, the remaining foetus and placenta grew to the size characteristic of a singleton conceptus (Vatnick et al., 1991). The number of placentomes of the remaining conceptus was similar to the average number of placentomes for twins, but significantly lower than the average number of placentomes for pregnancies with a singleton conceptus.

\section{Angiogenic factors}

The increase in the vascular density of cotyledons in pregnancies with twin compared with singleton conceptuses has been associated with increased expression of VEGF

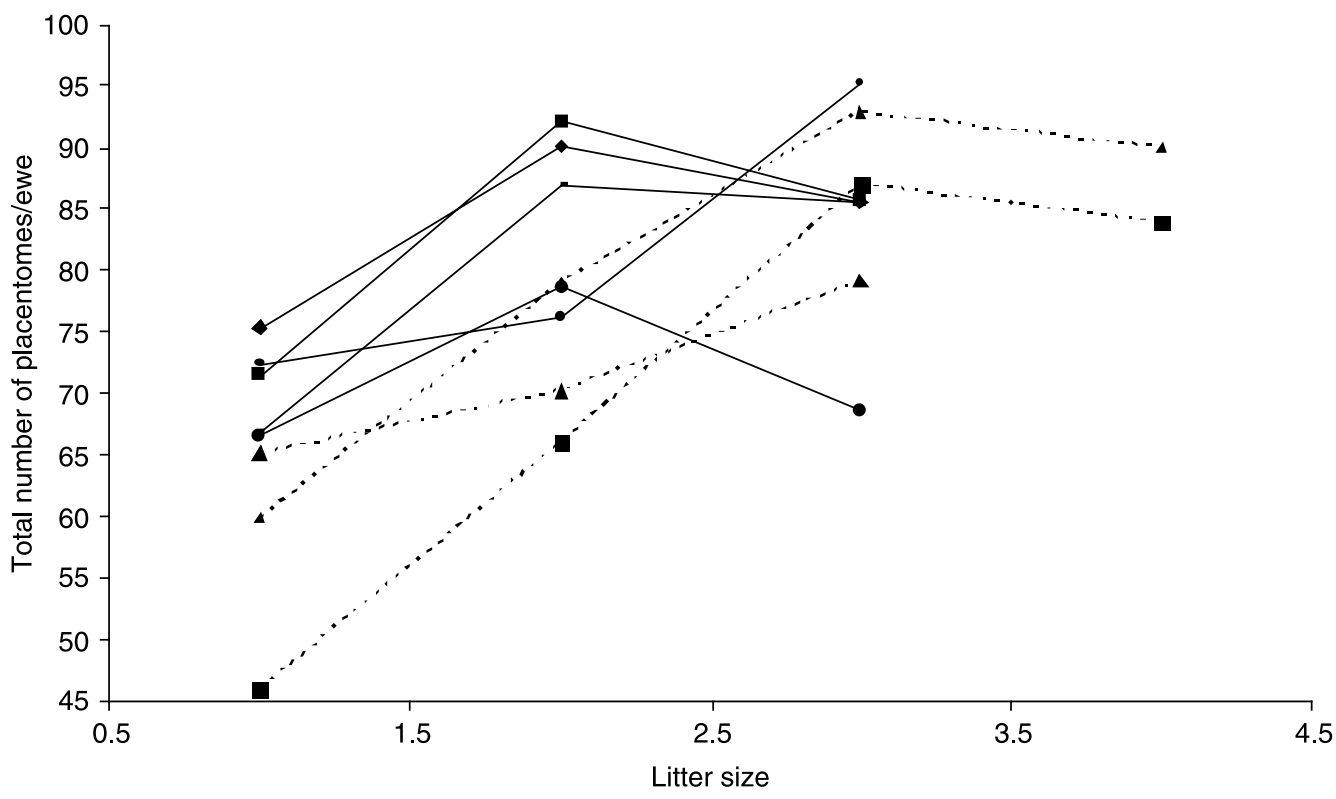

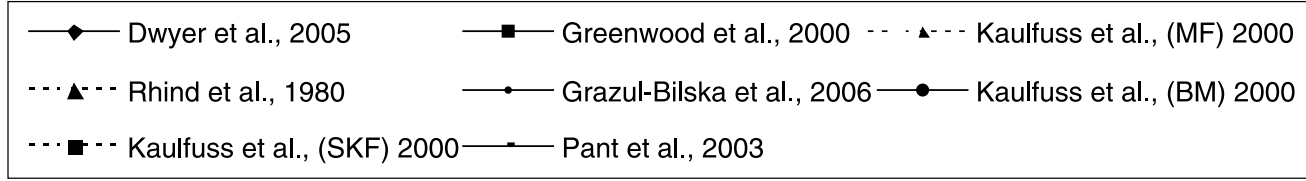

Figure 6 Association between litter size and number of placentomes per foetus according to different studies. 


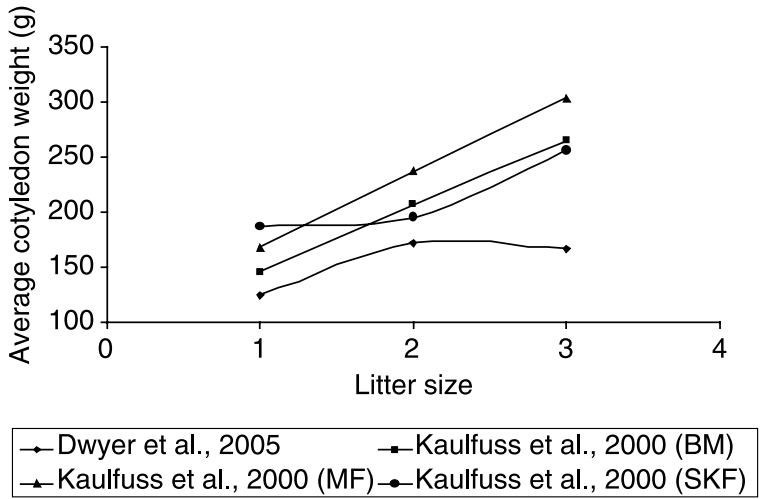

Figure 7 Association between litter size and average weight of cotyledons according to different studies.

and VEGF receptors at 140 days of gestation (Johnson et al., 2005). However, a further increase in VEGF and its receptors was not detected in cotyledons of ewes carrying triplet compared with twin conceptuses. Thus, twins and triplets appear to differ in their ability to induce mechanisms involved in stimulating angiogenesis in placentomes. Measurements of $\mathrm{NOx}$, defined as total plasma $\mathrm{NO}_{2}$ and $\mathrm{NO}_{3}$ in pregnant ewes (Magness et al., 2001), revealed that ewes pregnant with twins and triplets had more NOx than ewes carrying a single foetus.

\section{Cardiovascular and uterine blood flow}

Alterations in the cardiovascular system during pregnancy in sheep include decreases in arterial blood pressure, systemic vascular resistance and uterine vascular resistance, but increases in heart rate, cardiac output and blood volume. In sheep, the decrease in systemic vascular resistance, and the increase in cardiac output and expansion of blood volume are greater for ewes with multiple foetuses than singleton foetuses (Magness, 1998). Uterine arterial blood flow in ewes carrying twins at 120 to 130 days of gestation is 1.30- to 1.53-fold higher than in ewes carrying single foetuses (Christenson and Prior, 1978). However, when blood flow per $\mathrm{kg}$ foetus per min was considered, blood flow in twin conceptuses was on average only 0.87 of that of singleton conceptuses. Similarly, total uterine blood flow in ewes carrying triplets was 1.46-fold higher than for ewes carrying twins at 105 days of gestation, but uterine blood flow per $\mathrm{kg}$ foetus per min was similar for ewes with twin and triplet foetuses. An approx. 1.2-fold increase in total uterine blood flow was found in ewes carrying twin conceptuses compared with a singleton conceptus at 120 to 140 days of gestation (Caton et al., 1979).

Experimental reduction of uterine blood flow in ewes has been achieved by arterial occlusion and by the induction of embolisms using microspheres (Gagnon, 2003). Daily injection of microspheres for 21 days into the foetal abdominal aorta during the last trimester of pregnancy decreased foetal arterial oxygen content, which was followed by a $28 \%$ reduction in foetal weight (Murotsuki et al., 1996). Extreme (45\%) or moderate (30\%) reductions in uterine blood flow following arterial occlusion from day 113 to day 138 of gestation decreased foetal weights by 33 and $15 \%$, and placental weights by 34 and $27 \%$, respectively (Lang et al., 2000). Interestingly, the degree of reduction in foetal and placental weights in the extreme and moderately restricted blood-flow groups resembled the decrease in BWTs and placental weights in twins and triplets, respectively, compared with BWTs and placental weights for singleton conceptuses (Figure 5). A reduction in uterine blood flow is associated with an increase in the efficiency of nutrient transport from maternal to foetal blood (Owens et al., 1987), but with a significant decrease in oxygen delivery and foetal arterial oxygen content (Boyle et al., 1996).

\section{Nutrient levels}

Glucose is the main source of energy for the growing foetus. During the last trimester of pregnancy, concentrations of glucose are stable in both the maternal and foetal circulations. Increases in total foetal body mass in pregnancies with multiple foetuses raise the demand for glucose. Accordingly, plasma concentrations of glucose in the foetus and ewe in the case of twin pregnancies are $20 \%$ and $30 \%$ less, respectively, than for singleton pregnancies during late gestation (Edwards and McMillen, 2002; Vonnahme et al., 2003). The decline in plasma glucose concentration may be associated with changes in glucosetransporter abundance or activity; however, this has never been investigated in multiple pregnancies. Concentrations of free fatty acids and urea in the maternal plasma are similar for ewes with single and twin foetuses (Budge et al., 2003). Although recent reports indicate significant changes in amino acid metabolism in the sheep conceptus during gestation, these changes have been studied in nonprolific ewes (Wu et al., 2006).

Function of the hypothalamic-pituitary-adrenal (HPA) axis It is well established that the foetal HPA axis is activated during the pre-partum period and that the increase in circulating levels of cortisol in the foetus is important for both organ development and normal timing of parturition (Liggins, 1994). However, HPA-axis function appears to be suppressed in twin compared with single foetuses based on lower concentrations of ACTH and cortisol in the plasma and delayed onset of the pre-partum cortisol surge that determines time of parturition (Edwards and McMillen, 2002; Gardner et al., 2004). Interestingly, activation of the foetal HPA axis, as indicated by the initial increase in cortisol over basal levels, does not occur simultaneously in twins, even when they have similar BWTs (Schwartz and Rose, 1998).

Plasma levels of prolactin (PRL), placental lactogen (PL) and growth hormone (GH)

Concentrations of both PRL and PL in maternal blood during late gestation are directly related to litter size (Butler et al., 1981; Leibovich et al., 2000). Both PRL and PL 
bind to PRL receptors (PRLRs), which are more abundant in adipose tissues of twin than singleton foetuses. Interestingly, PRLR abundance in livers was not found to be related to litter size (Budge et al., 2003).

$\mathrm{GH}$ is expressed in the sheep placenta mainly during the early stages of pregnancy and it is involved in regulating endometrial gland proliferation and function (Spencer et al., 1999). Interestingly, Valinsky et al. (1990), showing the occurrence of gene duplication in the ovine $\mathrm{GH}$ locus, found two alleles: the GH1 allele with a single GH copy, and the $\mathrm{GH} 2$ allele with two gene copies designated $\mathrm{GH}_{2}$ $\mathrm{N}$ and GH2-Z. The GH2 allele is found in wild sheep and is the more frequent allele in most of the domesticated sheep breeds studied ( $E$. Gootwine, unpublished results).

The duplicated copy of the $\mathrm{GH} 2$ allele is expressed in the placenta but not in the pituitary and differs from the original gene copy by two non-synonymous substitutions in the open reading frame (Ofir and Gootwine, 1997). The recombinant product of the duplicated copy of the ovine GH gene manifests ca. 10-fold higher binding affinity for the $\mathrm{GH}$ receptor than the product of the original $\mathrm{GH}$ gene copy (Gootwine et al., 2006a). Interestingly, not all sheep carry the gene duplication. Thus, in pregnancies with multiple foetuses, conceptuses carrying the duplicated gene copy may have a selective advantage in a competition with sibling foetuses.

Plasma levels of progesterone and oestrogen In sheep, plasma concentrations of progesterone increase continually throughout most of gestation. By 90 days of gestation, one-half of the estimated circulating levels of progesterone are derived from the corpus luteum and the other half from the placenta. Sulphated oestrogens are the primary oestrogens present in both maternal blood and foetal fluids throughout gestation. There are two periods of high oestrogen production by the placenta: the first is between days 31 and 46 and the second is after mid gestation. By day 90 of pregnancy, it is estimated that $90 \%$ or more of the circulating oestradiol-17 $\beta$ has been secreted by the placenta. Interestingly, circulating levels of progesterone and oestrogens are higher in twin than singleton pregnancies (reviewed by Magness (1998)).

Plasma levels of pregnancy-associated glycoproteins Pregnancy-associated glycoproteins (PAGs) belong to a multigene protein family (Hughes et al., 2000) which is related to aspartic proteinases. The PAG I group is expressed throughout pregnancy by the binucleated cells of the trophectoderm, while the PAG II group is expressed throughout the trophectoderm. In sheep, PAGs are secreted in a relatively constant manner during pregnancy and can be detected in the maternal serum at as early as day 20 of pregnancy.

Maternal plasma PAG level increases with an increase in foetal number, and this foetal-number effect is evident at as early as 25 days of gestation (Willard et al., 1995;
Ranilla et al., 1997; Vandaele et al., 2005). Use of PAG serum levels to predict litter size based on PAG concentration in early gestation was found to not be useful (Vandaele et al., 2005).

\section{Foetal kidney development}

The abundance of mRNAs for genes that regulate foetal kidney development, i.e., IGF1, IGF1 receptor, IGF2, IGF2 receptor, GH receptor and glucocorticoid receptor, is lower in kidneys of twin versus singleton foetuses and inadequate maternal nutrition enhances these differences (Brennan et al., 2005).

\section{Foetal and placental growth in other natural IUGR models}

Altitude effects

The BWTs of lambs born to ewes at high altitude and exposed to hypobaric hypoxia were $24 \%$ lower than those of lambs born to ewes at or near sea level (Parraguez et al., 2005). However, placental weights were about 30\% higher for lambs born at high altitude compared with those for lambs born at low altitude (Parraguez et al., 2006). The effect of oxygen pressure on BWT was demonstrated experimentally by exposing ewes to hypobaric concentrations of oxygen, which resulted in reduced BWTs, without any change in placental weight (Jacobs et al., 1988).

\section{Age effect}

IUGR is evident in both primiparous and multiparous ewes. In Polypay ewes, lamb BWTs increased from $76 \%$ of maximum for ewes (lambing at 11 months of age to maximum for ewes lambing at 76 months of age, and then declined to $97 \%$ of maximum for ewes lambing at 105 months of age (Notter et al., 2005). Similar results were obtained with Assaf ewes (Figure 8; Gootwine and Rozov, 2006), which produced the heaviest lambs at their third parity. Increasing lamb BWTs up to the third parity were associated with increases in placental weight (Dwyer et al., 2005).

Primiparous ewes have usually not reached their mature body weight and therefore, foetal nutritional demands may be in conflict with maternal nutritional needs. Indeed, it was found (E. Gootwine, unpublished data) that age at first lambing does not affect BWTs of singleton lambs born to primiparous Assaf ewes lambing at 11 to 20 months of age (Figure 9). Only at 21 months of age were BWTs of lambs born to primiparous ewes found to be similar to BWTs of lambs born to mature multiparous ewes.

Age-dependent IUGR in primiparous ewes has been associated with reduced expression of a number of angiogenic factors at 135 days of pregnancy, including expression in placentomes of VEGF, angiopoietin (ANG1), the ANG receptor Tie-2, endothelial NO synthase (eNOS) and soluble guanylate cyclase $(\mathrm{sGC})$. Interestingly, these 


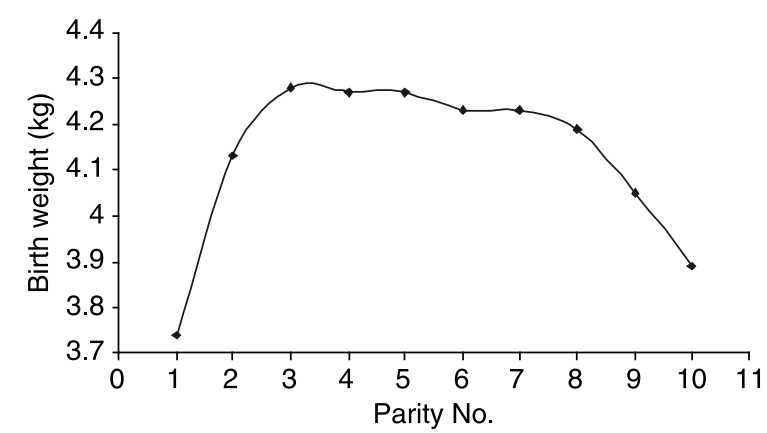

Figure 8 Least-squares means for birth weights of lambs relative to parity of ewes (after Gootwine and Rozov (2006)).

reductions in gene expression occurred in the cotyledonary, but not caruncular components of the placentomes (Borowicz et al., 2005).

\section{Breeding out of season}

One environmental factor that has a significant effect on lamb BWT is season. Lambs born in the autumn (short days) are, on average, $0.7 \mathrm{~kg}$ lighter than those born in spring (long days), regardless of litter size (Gootwine and Rozov, 2006). The reduction in foetal growth rate due to seasonal effects is first manifested at mid gestation, and gradually progresses as pregnancy advances, with reductions in the weights of cotyledons, but not caruncles, within placentomes (McCoard et al., 1996).

\section{Litter-size-dependent IUGR and nutritional insult}

\section{Maternal undernutrition}

Maternal undernutrition may lead to lower BWTs of foetuses and their placentae at term, depending on the severity and timing of the nutritional insult, either before or during pregnancy, and on the ewes' body condition during pregnancy. Moderate or severe undernutrition during mid or late gestation reduces lamb BWT (Heasman et al., 1999; Anthony et al., 2003; Redmer et al.,

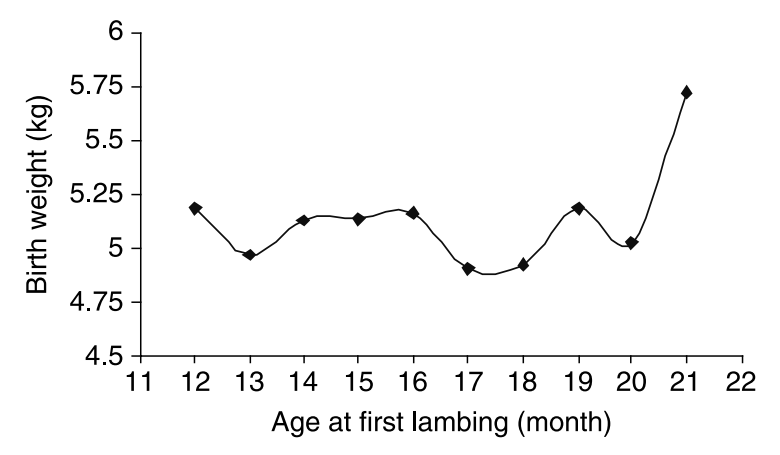

Figure 9 Least-squares means for birth weights of lambs born as singletons to primiparous Afec-Assaf ewes, according to age of ewe at lambing ( $n=361$, at least 15 ewes per age group).
2004; Luther et al., 2005). Interestingly, undernutrition can also cause relative increases in the weights of specific foetal organs, such as the heart and lungs (Harding and Johnston, 1995).

Complete fasting in ewes carrying singeltons results in lower concentrations of glucose and amino acids in the maternal blood, a marked reduction in uterine blood flow, and decreases in uterine uptake of glucose and amino acids (Morriss et al., 1980). Undernutrition to $70 \%$ of nutrient requirements (National Research Council (NRC), 1985) throughout gestation also reduced maternal and foetal concentrations of blood glucose in singeltons' pregnancies (Edwards and McMillen, 2002). Similarly, restriction to $50 \%$ of nutrient requirements (NRC, 1985) for pregnant ewes carrying singeltons between days 28 and 78 of gestation significantly reduced foetal and placental weights, as well as concentrations of total amino acids and polyamines in both the maternal and foetal plasma (Vonnahme et al., 2003; Kwon et al., 2004).

Litter-size-dependent IUGR is similar to IUGR resulting from maternal undernutrition. Both cases are associated with an inadequate supply of nutrients to the growing foetus, due to reduction in uterine blood flow and lower concentrations of metabolites in the maternal and foetal circulations. It can therefore be anticipated that undernutrition of twin-bearing ewes will enhance physiological symptoms that are already observed in singleton foetuses gestated in undernourished mothers. Surprisingly, several studies (Table 3) indicate that twin foetuses respond differently from singleton foetuses to maternal undernutrition (Table 3).

\section{Maternal overnutrition}

Re-alimentation of ewes following a period of undernutrition restores normal foetal growth (Kwon et al., 2004). On the other hand, overfeeding ewes carrying multiple foetuses does not promote foetal growth to individual BWTs that are similar to those for singleton lambs. In an experiment in which gestating Afec-Assaf ewes were offered a diet calculated to meet the nutritional requirements of ewes carrying triplets (NRC, 1985), ewes that conceived naturally following oestrus synchronisation and carried triplets did not experience a loss in body weight during gestation and their pre-mating and post-partum body weights were similar (E. Gootwine, unpublished results; Figure 10). However, feeding the same diet to ewes with twins increased post-partum body weight of the ewes, but not the BWTs of the lambs. Ewes carrying four, five or six foetuses lost weight during pregnancy when fed the same diet.

Overnourishing adolescent ewes throughout gestation results in significant restriction in placental and foetal growth (Wallace et al., 2006). Similar to litter-size-dependent IUGR, maternal overnutrition does not increase BWT of foetuses gestated in adolescent ewes that manifest agedependent IUGR (Wallace et al., 2005). 


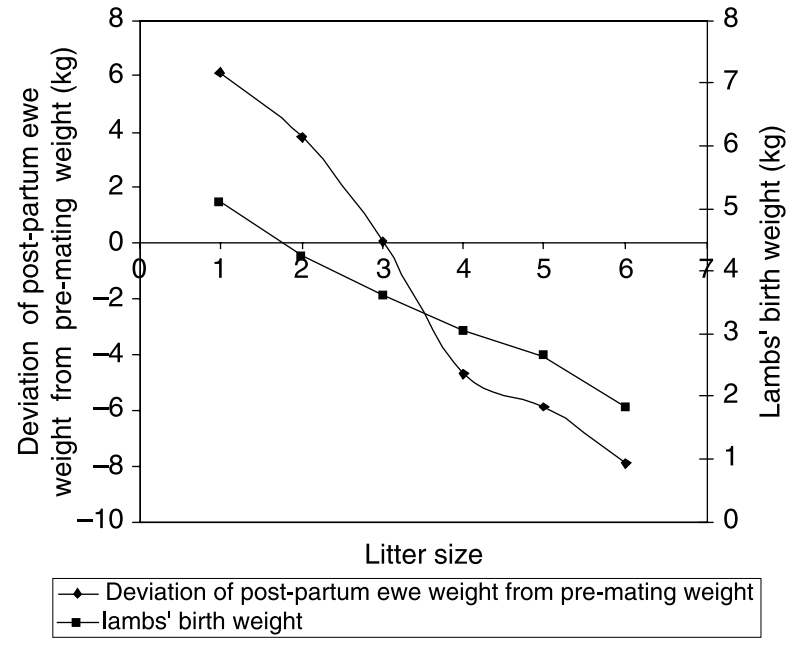

Figure 10 Birth weights of lambs and deviation of maternal body weight post partum from pre-mating in an experiment where Afec-Assaf ewes (Volcani Center, Israel) were fed to meet the nutritional requirements of ewes carrying triplets $(n=7,25,77,37,11$ and 3 for litter sizes of 1, 2, $3,4,5$ and 6 , respectively).

\section{Short- and long-term effects of large litter size on lamb health and performance}

Short-term effects

Lower BWT for individual lambs born in large litters affects prenatal and neonatal survival (Fogarty et al., 2000; Kleemann and Walker, 2005). The survival rate of lambs $(n=31)$ whose BWT was 1.5 or less was as low as 0.42 , although all were raised artificially (E. Gootwine, unpublished results). The lowest BWT for a lamb from that group that survived until 5 months of age was $1.0 \mathrm{~kg}$. The BWT of lambs also affects health (Ross et al., 2005), behaviour (Dwyer et al., 2005) and postnatal body composition.

Lower BWT is associated with reduced postnatal growth rate (Greenwood and Bell, 2003; Gootwine et al., 2006b). Even after BWT is included in a statistical model analysing lamb growth rate up to 5 months of age (Table 4), growth rate of lambs born as triplets and quadruplets is significantly lower than that of lambs born as singletons, suggesting that litter-size-dependent factors besides BWT are responsible for the relatively low postnatal growth ability of those lambs.

\section{Long-term effects}

IUGR and low BWT of human infants have received special attention because of their long-term effects on adult onset of various diseases (Gluckman and Pinal, 2003; Schwartz and Morrison, 2005; Bloomfield et al., 2006b; De Boo and Harding, 2006; Fowden et al., 2006a; Murphy et al., 2006). Similarly, low BWT was found to have long-term effects in sheep on glucose tolerance and blood pressure at 5 months but not at 30 months of age, and long-term effects at 30 months but not at 5 months of age on insulin tolerance and circulating levels of IGF1 (Oliver et al., 2002). BWT also affects HPA-axis function as studied in 10-month-old ewes (Bloomfield et al., 2006a) and this effect was similar for both singleton- and twin-born ewes.

Information on possible long-term effects of litter-sizedependent IUGR on sheep health, longevity, and reproduction and production performance is almost unavailable in the literature. The common practice of selecting only a portion of ewe lambs and only a few ram lambs as replacements, interferes with analyses of field records for longterm effects of litter size on performance as adults. Taking this into consideration, it was reported (Gootwine et al., 2006b) that mature BWs of Assaf ewes are not affected by litter size and, therefore, by their BWTs.

Undernutrition of ewes during gestation may have longterm effects on the health of their progeny. Indeed, undernutrition effects on ewes were observed for up to 3 years after birth as their offspring had higher resting blood pressures and heart rates than control progeny, and decreased heart rates in response to norepinephrine-induced increases in blood pressure (Gopalakrishnan et al., 2004). Undernutrition to $50 \%$ of requirements (NRC, 1985) during early to mid gestation impaired renal nephrogenesis, increased arterial blood pressure and increased expression of angiotensin-converting enzyme (ACE) in the renal cortex and expression of angiotensin II receptor (AT2) in the renal medulla of 9-month-old lambs, independent of effects on BWT (Gilbert et al., 2005). In addition, the consequences of undernutrition of ewes with single and twin foetuses were tested using the intravenous glucose tolerance test in their progeny at 1 year of age. It was found that glucoseinsulin homeostasis is indeed affected by undernutrition of the dams, but is independent of foetus number, despite the fact that BWTs of lambs born as singletons and twins differed (Gardner et al., 2005).

Undernutrition during the prenatal period has also been shown to reduce reproductive capacity throughout the adult life of female offspring: ewes from mothers that experienced undernutrition to $50 \%$ of estimated metabolisable energy requirements for pregnancy, from mating until day 95 of gestation, had reduced ovulation rates at 20 months of age (Rae et al., 2002). On the other hand, the reproductive function of male offspring in the same study was unaffected by prenatal undernutrition.

\section{New paradigm for litter-size-dependent IUGR}

Reduced numbers of placentomes leading to smaller placenta has been associated with relatively low BWTs of individual lambs born in large litters. However, results of several studies indicate that the placenta can manifest compensatory growth under conditions of reduced numbers of placentomes and limited uterine space, such that foetal development and BWTs are normal for single lambs (Alexander, 1964a; Caton et al., 1984). Such compensatory growth of the conceptus does not normally occur in pregnancies with multiple foetuses. In contrast, compensatory growth of the conceptus did occur when one of two twin 
Table 3 Response of sheep singleton and twin foetuses to various maternal-undernutrition treatments. Ewes' diet is expressed as percentage of normal requirements (National Research Council, 1985)

\begin{tabular}{|c|c|c|c|c|}
\hline Treatment & Trait under investigation & Singletons & Twins & Reference \\
\hline $\begin{array}{l}\text { Maternal undernutrition }(70 \%) \\
\text { from day } 8 \text { to day } 147 \text { of gestation. }\end{array}$ & Birth weight & Not affected & Reduced & $\begin{array}{l}\text { Edwards and McMillen, 2002; } \\
\text { Edwards et al., } 2005 .\end{array}$ \\
\hline $\begin{array}{l}\text { Maternal undernutrition ( } 50 \%) \\
\text { from day } 28 \text { to day } 78 \text { of gestation. }\end{array}$ & Caruncle vascularity & Not affected & Enhanced & Vonnahme et al., 2003. \\
\hline $\begin{array}{l}\text { Maternal undernutrition during } \\
\text { mid-gestation which was associated } \\
\text { with lower BTW. }\end{array}$ & Uterine blood flow & Reduced & Not affected & Newnham et al., 1991. \\
\hline $\begin{array}{l}\text { Maternal undernutrition from } 60 \text { days } \\
\text { before until } 7 \text { days after mating. }\end{array}$ & ACTH blood levels & Not affected & Increased & Edwards and McMillen, 2002. \\
\hline $\begin{array}{l}\text { Maternal undernutrition during the } \\
\text { first } 110 \text { days of gestation. }\end{array}$ & Kidney fat deposition & Increased & Not affected & Brennan et al., 2005. \\
\hline $\begin{array}{l}\text { Maternal undernutrition during the } \\
\text { first } 110 \text { days of gestation. }\end{array}$ & Abundance of mRNA in the kidney & Increased & Not affected & Brennan et al., 2005. \\
\hline $\begin{array}{l}\text { Maternal undernutrition }(60 \%) \\
\text { through gestation. }\end{array}$ & $\begin{array}{l}\text { Abundance of cytochrome c and voltage-dependent } \\
\text { anion channel in adipose tissue }\end{array}$ & Not affected & Increased & Budge et al., 2003. \\
\hline $\begin{array}{l}\text { Maternal undernutrition }(70 \%) \\
\text { periconceptional or through gestation. }\end{array}$ & $\begin{array}{l}\text { Relationship between maternal and fetal leptin } \\
\text { plasma concentrations }\end{array}$ & No association & Significant association & Edwards et al., 2005. \\
\hline $\begin{array}{l}\text { Maternal under nutrition }(30 \%) \\
\text { periconceptional or through gestation. }\end{array}$ & $\begin{array}{l}\text { Association between ewes' live weight at mating } \\
\text { and concentration of plasma leptin at late gestation }\end{array}$ & Not related & Positive association & Edwards et al., 2005. \\
\hline
\end{tabular}


Table 4 Least-squares mean values for birth weight (BWT) and growth rate (GR) up to 5 months of age of Afec-Assaf lambs (following Gootwine et al., 2006b). Main effects included in the statistical model for BWT and GR (model 1) were: sire, lambing group (crop), parity number, sex of lamb and litter size. BWT of the lambs was included in model 2

\begin{tabular}{|c|c|c|c|c|}
\hline Litter size & No. of litters & BWT (kg) & $\begin{array}{c}\text { Growth rate (g/day) up to } 5 \text { months } \\
\text { of age (model } 1 \text { ) }\end{array}$ & $\begin{array}{c}\text { Growth rate (g/day) up to } 5 \text { months } \\
\text { of age (model } 2 \text { ) }\end{array}$ \\
\hline 1 & 1371 & $5.4^{a} \pm 0.03$ & $291^{a} \pm 2$ & $276^{a} \pm 2$ \\
\hline 2 & 1540 & $4.4^{b} \pm 0.03$ & $274^{b} \pm 2$ & $272^{\mathrm{ab}} \pm 2$ \\
\hline 3 & 777 & $3.6^{c} \pm 0.03$ & $264^{c} \pm 2$ & $272^{b} \pm 2$ \\
\hline 4 & 248 & $3.0^{d} \pm 0.04$ & $250^{d} \pm 2$ & $267^{c} \pm 2$ \\
\hline
\end{tabular}

a,b,c,d Within a column, means with different letters differ significantly $(P<0.05)$.

foetuses was removed at day 50 of gestation, to allow for enhanced growth of the remaining conceptus to that characteristic of a singleton (Vatnick et al., 1991). These results clearly suggest that in multi-foetal pregnancies, reduced placentome number does not account for foetal IUGR.

Possible explanations for litter-size-dependent IUGR might be the inability of the maternal system fully to meet nutrient demands of multiple conceptuses, mutual growth interference among sibling foetuses, and maternal inhibition of placental and foetal growth in the case of multiple conceptuses by downregulation genes controlling placental growth and nutrient transport, as was noted in the case of maternal genomic imprinting (Isles and Holland, 2005; Angiolini et al., 2006; Cattanach et al., 2006; Fowden et al., 2006b).

\section{Litter-size-dependent IUGR and nutrition insult}

The observations that blood flow per foetus in twin pregnancies is less than that in singleton pregnancies (Christenson and Prior, 1978), and that concentrations of glucose in the maternal and foetal circulations are lower in twin than in singleton pregnancies (Vonnahme et al., 2003), support the notion that litter-size-dependent IUGR results from the maternal system's inability fully to support growth of multiple conceptuses. However, three lines of evidence suggest that nutrient supply from the dam to the conceptus may not be the sole rate-limiting factor for foetal growth in pregnancies with multiple foetuses, or at least for twin pregnancies.

- Litter-size-dependent IUGR is evident at about day 100 of pregnancy (Winters and Feuffel, 1936; Naaktgeboren and Stegeman, 1969; Rattray et al., 1974), when foetal size and growth rate are minimal, but placental size is maximal (Figure 5). Interestingly, the conclusion that the foetal growth trajectory in twins is determined early in gestation can also be drawn from studies of women with multiple conceptuses (Alexander et al., 1995), in which foetal number was reduced early in pregnancy. In those studies, foetal size and gestation length were related to the initial number of foetuses and not to the number of foetuses present at delivery.

- Total weight of foetuses in a litter increases as litter size increases (Freetly and Leymaster, 2004). Thus, total weight of triplets and quadruplets at birth is more than twice that of the BWT of single lambs, indicating that the ewe could support growth of each twin to the size of a singleton lamb.

- Overnutrition of ewes with twin conceptuses increases maternal body weight rather than enhancing intrauterine growth of the twin foetuses (Figure 10).

Litter-size-dependent IUGR and mutual foetal growth inhibition

Mutual growth interference among sibling foetuses can be mediated by direct interactions between placentae of conceptuses in the same uterus. However, to date, there is no experimental evidence in sheep to support this hypothesis.

Litter-size-dependent IUGR and placental reprogramming An alternative explanation for litter-size-dependent IUGR is that the patterns of placental and foetal growth are reprogrammed in pregnancies with multiple foetuses such that they do not follow their normal course of intrauterine development as determined by their genetic potential. This reprogramming event may take place at mid gestation, after day 50 of pregnancy, as it was shown that conceptuses at that stage retain their full growth potential (Vatnick et al., 1991).

Regulation of foetal growth involves multidirectional interactions between the mother, the placenta and the foetus (Murphy et al., 2006). Reprogramming patterns of conceptus growth by attenuating placental growth and function, i.e. nutrient transport and hormone production (Spencer et al., 2004), may limit foetal growth to term, as foetal size is clearly correlated with size of the placenta (Greenwood et al., 2000). The reduction in size and function of individual placenta in pregnancies with multiple conceptuses may result from both reduced placental cell proliferation and, possibly, increases in apoptosis early in gestation, as observed in a well-fed adolescent IUGR experimental model (Lea et al., 2005).

The mechanism(s) that induces the proposed litter-sizedependent IUGR is not yet clear. However, it may involve endocrine signals from the maternal compartment. Indeed, a mechanism whereby maternal hormones affect conceptus growth has been proposed for season-dependent IUGR (Gootwine and Rozov, 2006), where seasonal variation in 
BWT was proposed to be related to the pattern of maternal melatonin secretion.

Adaptation of placental and foetal growth to a multifoetal pregnancy situation can be mediated through alterations in the expression of placental and foetal imprinted genes, shown to be involved in the control of foetal growth and nutrient-transport efficiency through the placenta (Angiolini et al., 2006). As maternal imprinted genes are more involved in restraining placental and foetal growth, their down-regulation in multi-foetal pregnancies can be suggested as a mechanism underlying litter-sizedependent IUGR.

Reprogramming foetal growth during litter-size-dependent IUGR relies on the recognition of pregnancies involving multiple conceptuses. The signal for the presence of more than one foetus can be circulating levels of PAGs (Hughes et al., 2000) or circulating levels of hormones produced by the placenta during mid gestation, i.e. progesterone and oestrogens (Magness, 1998), and members of the GH-PRL family (Anthony et al., 1995). The plasma concentrations of all of these factors are positively correlated with numbers of conceptuses.

\section{Litter-size-dependent IUGR as a foetal protective mechanism}

The relatively low BWTs of individual lambs born in large litters may negatively affect their neonatal and postnatal survival rates (Kleemann and Walker, 2005). However, the adaptive mechanisms in pregnancies with multiple conceptuses that delay placental and foetal growth at mid-gestation may have the advantage of protecting foetuses from nutritional insults during advanced stages of gestation, when their daily weight gains are maximal. Indeed, Harding and Johnston (1995) reported that foetuses growing slowly before the onset of undernutrition of their dams do not further reduce their growth rates. In addition, restricted foetal growth rates reduce the risk of pregnancy toxemia which, in sheep, may result in death of both the mother and its foetuses.

Further studies are needed to understand the mechanisms that regulate foetal growth in multi-foetal pregnancies and how those mechanisms may differ from mechanisms that control growth and development of singleton foetuses. The same signals that may restrict foetal growth in multifoetus pregnancies may, under pathological conditions, induce IUGR in singleton pregnancies.

\section{References}

Albrecht ED and Pope GJ 1985. The placenta remains functional following fetectomy in baboons. Endocrinology 116, 843-845.

Alexander G. 1964a. Studies on the placenta of the sheep (Ovis aries L). Effect of surgical reduction In the number of caruncles. Journal of Reproduction and Fertility 7, 307-322.

Alexander G 1964b. Studies on the placenta of the sheep (Ovis aries L). Placental size. Journal of Reproduction and Fertility 7, 289-305.

Alexander JM, Hammond KR and Steinkampf MP 1995. Multifetal reduction of high-order multiple pregnancy: comparison of obstetrical outcome with nonreduced twin gestations. Fertility and Sterility 64, 1201-1203.
Allen WR, Wilsher S, Turnbull C, Stewart F, Ousey J, Rossdale PD and Fowden AL 2002. Influence of maternal size on placental, fetal and postnatal growth in the horse. I. Development in utero. Reproduction 123, 445-453.

Al-Shorepy SA 2001. Estimates of genetic parameters for direct and maternal effects on birth weight of local sheep in United Arab Emirates. Small Ruminant Research 39, 219-224.

Al-Shorepy SA and Notter DR 1998. Genetic parameters for lamb birthweight in spring and autumn lambibg. Animal Science 67, 327-332.

Angiolini E, Fowden A, Coan P, Sandovici I, Smith P, Burton G, Tycko B, Reik W, Sibley C and Constância M 2006. Regulation of placental efficiency for nutrient transport by imprinted Genes. Placenta 27, S98-S102.

Anthony RV, Liang R, Kayl EP and Pratt SL 1995. The growth hormone/prolactin gene family in ruminant placentae. Journal of Reproduction and Fertility Supplement 49, 83-95.

Anthony RV, Limesand SW, Fanning MD and Liang R 1998. Placental lactogen and growth hormone: regulation and action. In The endocrinology of pregnancy (ed. FW Bazer), pp. 461-490, Humana Press Inc., Totowa, NJ.

Anthony RV, Scheaffer AN, Wright CD and Regnault TR 2003. Ruminant models of prenatal growth restriction. Reproduction Supplement 61, 183-194.

Bazer FW, Roberts RM, Basha SM, Zavy MT, Caton D and Barron DH 1979. Method for obtaining ovine uterine secretions from unilaterally pregnant ewes. Journal of Animal Science 49, 1522-1527.

Bishop SC and Mackenzie K 2001. The inheritance of traits describing early lamb performance in Scottish Blackface sheep. Proceedings of the British Society of Animal Science 2001, p. 43.

Björkman N 1970. An atlas of placental fine structure. Baillière Tindall \& Cassell, London, UK.

Bloomfield FH, Oliver MH and Harding JE 2006a. Effects of twinning, birth size and postnatal growth on glucose tolerance and hypothalamo-pituitaryadrenal function in post-pubertal sheep. American Journal Physiology Endocrinology and Metabolism 29, (in press). doi: 101152/ajpendo.00210.2006.

Bloomfield FH, Oliver MH and Harding JE 2006b. The late effects of fetal growth patterns. Archives of Disease in Childhood Fetal and Neonatal Edition 91, F299-F304.

Borowicz PP, Vonnahme KA, Grazul-Bilska AT, Redmer DA, Johnson ML and Reynolds LP 2005. The effect of maternal age (age at first Pregnancy) on placental expression of the major angiogenic factors and their receptors. Journal of the Society for Gynecologic investigation 12, (suppl.) 327A.

Boyle DW, Lecklitner S and Liechty EA 1996. Effect of prolonged uterine blood flow reduction on fetal growth in sheep. The American Journal of Physiology 270, R246-R253.

Brennan KA, Gopalakrishnan GS, Kurlak L, Rhind SM, Kyle CE, Brooks AN, Rae MT, Olson DM, Stephenson T and Symonds ME 2005. Impact of maternal undernutrition and fetal number on glucocorticoid, growth hormone and insulin-like growth factor receptor mRNA abundance in the ovine fetal kidney. Reproduction 129, 151-159.

Bromley CM, Snowder GD and Van Vleck LD 2000. Genetic parameters among weight, prolificacy, and wool traits of Columbia, Polypay, Rambouillet, and Targhee sheep. Journal of Animal Science 78, 846-858.

Budge H, Dandrea J, Mostyn A, Evens $Y$, Watkins R, Sullivan C, Ingleton $P$, Stephenson T and Symonds ME 2003. Differential effects of fetal number and maternal nutrition in late gestation on prolactin receptor abundance and adipose tissue development in the neonatal lamb. Pediatric Research 53, 302-308.

Burfening PJ and Kress DD 1993. Direct and maternal effects on birth and weaning weight in sheep. Small Ruminant Research 10, 153-163.

Butler WR, Fullenkamp SM, Cappiello LA and Handwerger S 1981. The relationship between breed and litter size in sheep and maternal serum concentrations of placental lactogen, estradiol and progesterone. Journal of Animal Science 53, 1077-1081.

Butler TG, Schwartz J and McMillen IC 2002. Differential effects of the early and late intrauterine environment on corticotrophic cell development. Journal of Clinical Investigation 110, 783-791.

Carver TD and Hay WW 1995. Uteroplacental carbon substrate metabolism and $\mathrm{O}_{2}$ consumption after long term hypoglycemia in pregnant sheep. American Journal of Physiology 269, E299-E308.

Caton D, Crenshaw C, Wilcox CJ and Barron DH 1979. $O_{2}$ delivery to the pregnant uterus: its relationship to 02 consumption. The American Journal of Physiology 237, R52-R57. 
Caton D, Bazer FW, Kalra PS and Moffatt RJ 1984. Adaptations to reduction of endometrial surface available for placental development in sheep. Journal of Reproduction and Fertility 72, 357-364.

Cattanach BM, Beechey CV and Peters J 2006. Interactions between imprinting effects: summary and review. Cytogenetic and Genome Research 113, 17-23.

Christenson RK and Prior RL 1978. Uterine blood flow and nutrient uptake during late gestation in ewes with different number of fetuses. Journal of Animal Science 46, 189-200.

Christley RM, Morgan KL, Parkin TDH and French NP 2003. Factors related to the risk of neonatal mortality, birth-weight and serum immunoglobulin concentration in lambs in the UK. Preventive Veterinary Medicine 57, 209-226.

Corner RA, Kenyon PR, Stafford KJ, West DM and Morris ST 2006. The effect of maternal nutrition during gestation on the reproductive success of female progeny as 2-tooths. Proceedings of the New Zealand Society of Animal Production $66,434-438$.

Damgaard LH, Rydhmer L, Lovendahl P and Grandinson K 2003. Genetic parameters for within-litter variation in piglet birth weight and change in withinlitter variation during suckling. Journal of Animal Science 81, 604-610.

Danielson L, McMillen IC, Dyer JL and Morrison JL 2005. Restriction of placental growth results in greater hypotensive response to $\alpha$-adrenergic blockade in fetal sheep during late gestation. The Journal of Physiology 563, 611-620.

De Boo HA and Harding JE 2006. The developmental origins of adult disease (Barker) hypothesis. The Australian and New Zealand Journal of Obstetrics and Gynecology 46, 4-14.

Dickinson AG, Hancock JL, Hovell GJR, Taylor SCS and Wiener G 1962. The size of lamb at birth - a study involving egg transfer. Animal Production 4, 64-79.

Donald HP and Russell WS 1970. The relationship between live weight of ewe at mating and weight of newborn lambs. Animal Production 12, 273-280.

Dwyer CM, Calvert SK, Farish M, Donbavand J and Pickup HE 2005. Breed, litter and parity effects on placental weight and placentome number, and consequences for the neonatal behavior of the lamb. Theriogenology 63, 10921110.

Edwards LJ, McFarlane JR, Kauter KG and McMillen IC 2005. Impact of periconceptional nutrition on maternal and fetal leptin and fetal adiposity in singleton and twin pregnancies. American Journal of Physiology-Regulatory, Integrative and Comparative Physiology 288, R39-R45.

Edwards LJ and McMillen IC 2002. Impact of maternal undernutrition during the periconceptional period, fetal number, and fetal sex on the development of the hypothalamo-pituitary adrenal axis in sheep during late gestation. Biology of Reproduction 66, 1562-1569.

Feil R, Khosla S, Cappai P and Loi P 1998. Genomic imprinting in ruminants: allele-specific gene expression in parthenogenetic sheep. Mammalian Genome 9, 831-834

Ferrell CL 1991. Maternal and fetal influences on uterine and conceptus development in the cow: II. Blood flow and nutrient flux. Journal of Animal Science 69, 1954-1954.

Fogarty N 1995. Genetic parameters for live weight, fat and muscle measurements, wool production and reproduction in sheep: A review. Animal Breeding Abstract 63, 101-143.

Fogarty N, Hopkins D and van der Ven R 2000. Lamb production from diverse genotypes. 1. Lamb growth and survival and ewe performances. Animal Science 70, 135-145.

Fowden AL, Giussani DA and Forhead AJ 2006a. Intrauterine programming of physiological systems: causes and consequences. Physiology (Bethesda) 21, 29-37.

Fowden AL, Sibley C, Reik W and Constância M 2006b. Imprinted genes, placental development and fetal growth. Hormone Research 65, (suppl. 3) 50-58.

Fowden AL, Ward JW, Wooding FP, Forhead AJ and Constancia M 2006c. Programming placental nutrient transport capacity. The Journal of Physiology 572, 5-15.

Freetly HC and Leymaster KA 2004. Relationship between litter birth weight and litter size in six breeds of sheep. Journal of Animal Science 82, 612-618.

Gagnon R 2003. Placental insufficiency and its consequences. European Journal of Obstetrics \& Genecology and Reproduction Biology 110, S99-S107.

Gama L, Dickerson G, Young L and Leymaster K 1991. Effect of breed, heterosis, age of dam, litter size and birth weight on lamb mortality. Journal of Animal Science 69, 2727-2734.
Gardner DS, Jamall E, Fletcher AJ, Fowden AL and Giussani DA 2004. Adrenocortical responsiveness is blunted in twin relative to singleton ovine fetuses. The Journal of Physiology 557, 1021-1032.

Gardner DS, Tingey K, Van Bon BW, Ozanne SE, Wilson V, Dandrea J, Keisler DH, Stephenson T and Symonds ME 2005. Programming of glucose-insulin metabolism in adult sheep after maternal undernutrition. American Journal of Physiology-Regulatory, Integrative and Comparative Physiology 289, R947R954.

Gilbert JS, Lang AL, Grant AR and Nijland MJ 2005. Maternal nutrient restriction in sheep: hypertension and decreased nephron number in offspring at 9 months of age. The Journal of Physiology 565, 137-147.

Gluckman PD and Pinal CS 2003. Regulation of fetal growth by the somatotrophic axis. The Journal of Nutrition 133, 1741S-1746S.

Gootwine E 2004. Placental hormones and fetal-placental development. Animal Reproduction Science 82-83, 551-566.

Gootwine E 2005. High variability in the rate of decline in birth weight as litter size increases in sheep. Animal Science 81, 393-398.

Gootwine E, Bor A, Braw-Tal R and Zenou A 1993. Inheritance of birth weight and growth traits in crosses between the Booroola-Merino and Assaf sheep breeds. Livestock Production Science 33, 119-126.

Gootwine E, Reicher S and Gertler A 2006a. Ovine placental growth Hormone variant has higher binding affinity to the growth hormone receptor. Proceedings of the 39th annual meeting of the Society for the Study of Reproduction, abstract no. 344.

Gootwine E and Rozov A 2006. Seasonal effects on birth weight of lambs born to prolific ewes maintained under intensive management. Livestock Science 105, 277-283.

Gootwine E, Rozov A, Bor A and Reicher S 2006b. Carrying the FecB (Booroola) mutation is associated with lower birth weight and slower post weaning growth rate for lambs and lighter mature body weight for ewes. Reproduction Fertility and Development 18, 433-437.

Gootwine E, Rozov A and Weller JI 2006c. Factors affecting within-litter variation in birthweight of lambs. In Proceedings of the eighth world congress on genetics applied to livestock production. Belo Horizonte, Brazil, CR_ROM.

Gopalakrishnan GS, Gardner DS, Rhind SM, Rae MT, Kyle CE, Brooks AN, Walker RM, Ramsay MM, Keisler DH, Stephenson T and Symonds M 2004. Programming of adult cardiovascular function after early maternal undernutrition in sheep. American Journal of Physiology-Regulatory, Integrative and Comparative Physiology 287, R12-R20.

Gray CA, Bartol FF, Tarleton BJ, Wiley AA, Johnson GA, Bazer FW and Spencer TE 2001. Developmental biology of uterine glands. Biology of Reproduction $65,1311-1323$

Grazul-Bilska AT, Pant D, Luther JS, Borowicz PP, Navanukraw C, Caton JS, Ward MA, Redmer DA and Reynolds LP 2006. Pregnancy rates and gravid uterine parameters in single, twin and triplet pregnancies in naturally bred ewes and ewes after transfer of in vitro produced embryos. Animal Reproduction Science 92, 268-283.

Greenwood PL and Bell AW 2003. Consequences of intra-uterine growth retardation for postnatal growth, metabolism and pathophysiology. Reproduction Supplement 61, 195-206.

Greenwood PL, Slepetis RM and Bell AW 2000. Influences on fetal and placental weights during mid to late gestation in prolific ewes well nourished throughout pregnancy. Reproduction, Fertility and Development 12, 149-156.

Hagemann LJ, Peterson AJ, Weilert LL, Lee RS and Tervit HR 1998. In vitro and early in vivo development of sheep gynogenones and putative androgenones. Molecular Reproduction and Development 50, 154-162.

Hanford KJ, Van Vleck LD and Snowder GD 2002. Estimates of genetic parameters and genetic change for reproduction, weight, and wool characteristics of Columbia sheep. Journal of Animal Science 80, 30863098.

Hanford KJ, Van Vleck LD and Snowder GD 2003. Estimates of genetic parameters and genetic change for reproduction, weight, and wool characteristics of Targhee sheep. Journal of Animal Science 81, 630-640.

Harding JE and Johnston BM 1995. Nutrition and fetal growth. Reproduction, Fertility and Development 7, 539-547.

Heasman L, Clarke L, Stephenson TJ and Symonds ME 1999. The influence of maternal nutrient restriction in early to mid-pregnancy on placental and fetal development in sheep. Proceedings of the Nutrition Society $58,283-288$ 
Hinch G, Crosbie S, Kelly R, Owens J and Davis G 1985. Influence of birth weight and litter size on lamb survival in high fecundity Booroola-Merino crossbred flocks. New Zealand Journal of Agricultural Research 28, 31-38.

Holst $\mathrm{P}$, Fogarty NM and Stanley D 2002. Birth weight, meningeal lesions and survival of diverse genotypes of lambs from Merino and crossbred ewes. Australian Journal of agricultural Research 53, 175-181.

Hughes AL, Green JA, Garbayo J and Roberts RM 2000. Adaptive diversification within a large family of recently duplicated, placentally expressed genes. Proceedings of the National Academy of Science of the United States of America 97, 3319-3323.

Isles AR and Holland AJ 2005. Imprinted genes and mother-offspring interactions. Early Human Development 81, 73-77.

Jacobs R, Robinson JS, Owens JA, Falconer J and Webster ME 1988. The effect of prolonged hypobaric hypoxia on growth of fetal sheep. Journal of Developmental Physiology 10, 97-112.

Johnson ML, Reynolds LP, Redmer DA and Grazul-Bilska AT 2005. Expression of vascular endothelial growth factor (VEGF) and fibroblast growth factor (FGF-2) and their receptors in ovine placenta tissues from single, twin and triplet pregnancies. Journal of the Society for Gynecologic Investigation 12, 181A-182A.

Kaulfuss KH, Schramm D and Berttram M 2000. Effects of genotype, damage, litter size, birthweight and ram on morphological parameters of the placenta in sheep. Deutsche Tierärztliche Wochenschrift 107, 269-275.

Kenyon PR, Morrison ST, Revell DK and McCutcheon SN 2002. Maternal constraint and the birth weight response to mid-pregnancy shearing. Australian Journal of Agriculture Research 53, 511-517.

Kleemann DO and Walker SK 2005. Fertility in south Australian commercial merino flocks: source of reproductive wastage. Theriogenology 63, 2075-2088.

Kwon H, Ford SP, Bazer FW, Spencer TE, Nathanielsz PW, Nijland MJ, Hess BW and Wu G 2004. Maternal nutrient restriction reduces concentrations of amino acids and polyamines in ovine maternal and fetal plasma and fetal fluids. Biology of Reproduction 71, 901-908.

Lang U, Baker RS, Khoury J and Clark KE 2000. Effects of chronic reduction in uterine blood flow on fetal and placental growth in the sheep. American Journal of Physiology-Regulatory, Integrative and Comparative Physiology 279, R53-R59.

Lea RG, Hannah LT, Redmer DA, Aitken RP, Milne JS, Fowler PA, Murray JF and Wallace JM 2005. Developmental indices of nutritionally induced placental growth restriction in the adolescent sheep. Pediatric Research 57, 599-604.

Leibovich H, Gertler A, Bazer FW and Gootwine E 2000. Active immunization of ewes against ovine placental lactogen increases birth weight of lambs and milk production with no adverse effect on conception rate. Animal Reproduction Science 64, 33-47.

Liggins GC 1994. The role of cortisol in preparing the fetus for birth. Reproduction Fertility and Development 6, 141-150.

Luther JS, Redmer DA, Reynolds LP and Wallace JM 2005. Nutritional paradigms of ovine fetal growth restriction: implications for human pregnancy. Human Fertility (Cambridge) 8, 179-187.

McCoard SA, McNabb WC, Peterson SW, McCutcheon SN and Harris PM 2000. Muscle growth, cell number, type and morphometry in single and twin fetal lambs during mid to late gestation. Reproduction, Fertility and Development 12, 319-327.

McCoard SA, Peterson SW, Jenkinson CMC, Campbell JW and McCutcheon SN 1996. Seasonal effects on fetal growth in sheep. Proceedings of the New Zealand Society for Animal Production 56, 297-300.

McCoard SA, Peterson SW, McNabb WC, Harris PM and McCutcheon SN 1997. Maternal constraint influences muscle fiber development in fetal lambs. Reproduction, Fertility and Development 9, 675-681.

McLaren RJ and Montgomery GW 1999. Genomic imprinting of the insulinlike growth factor 2 gene in sheep. Mammalian Genome 10, 588-591.

MacLaughlin SM, Walker SK, Roberts CT, Kleemann DO and McMillen IC 2005. Periconceptional nutrition and the relationship between maternal body weight changes in the periconceptional period and feto-placental growth in the sheep. Journal of Physiology 565, 111-124.

McMillen IC, Adams MB, Ross JT, Coulter CL, Simonetta G, Owens JA, Robinson JS and Edwards $L$ 2001. Fetal growth restriction: adaptations and consequences. Reproduction 122, 195-204.

Magness RR 1998. Maternal cardiovascular and other physiologic responses to the endocrinology of pregnancy. Endocrinology of pregnancy (ed. FW Bazer), pp. 507-539, Humana Press Inc., Totowa, NJ.
Magness RR, Sullivan JA, Li Y, Phernetton TM and Bird IM 2001. Endothelial vasodilator production by uterine and systemic arteries. VI. Ovarian and pregnancy effects on eNOS and $\mathrm{NO}(\mathrm{x})$. American Journal of Physiolgy-Heart and Cirulatoryc Physiology 280, H1692-H1698.

Maria GA, Boldman KG and Van Vleck LD 1993. Estimates of variances due to direct and maternal effects for growth traits of Romanov sheep. Journal of Animal Science 71, 845-849.

Meyer K 1992. Variance components due to direct and maternal effects for growth traits of Australian beef cattle. Livestock Production Science 31, 179-204.

Moores RR Jr, Rietberg CC, Battaglia FC, Fennessey PV and Meschia G 1993. Metabolism and transport of maternal serine by the ovine placenta: glycine production and absence of serine transport into the fetus. Pediatric Research 33, 590-594.

Morriss FH, Rosenfeld CR, Carandell SS and Adcock EW III 1980. Effect of fasting on uterine blood flow and substrate uptake in sheep. Journal of Nutrition. 110, 2433-2443.

Mousa E, Van Vleck LD and Leymaster KA 1999. Genetic parameters for growth traits for a composite terminal sire breed of sheep. Journal of Animal Science 77, 1659-1665.

Murotsuki J, Gagnon R, Matthews SG and Challis RG 1996. Effect of longterm hypoxemia on pituitary-adrenal function in fetal sheep. American Journal of Physiology 271, E678-E685.

Murphy VE, Smith R, Giles WB and Clifton VL 2006. Endocrine regulation of human fetal growth: the role of the mother, placenta, and fetus. Endocrine Reviews 27, 141-169.

Naaktgeboren C and Stegeman JHJ 1969. Investigation on the influence of the uterus and the placenta on fetal growth and birth weight, under special consideration of sheep. Zeitschrift für Tierzüchtung und Züchtungsbiologie 85, 245-290.

Nasholm A and Danell 0 1996. Genetic relationships of lamb weight, maternal ability, and mature ewe weight in Swedish fine wool sheep. Journal of Animal Science 74, 329-339.

National Research Council 1985. Nutrient requirements of sheep. National Academy Press, Washington, DC.

Newnham JP, Kelly RW, Patterson L and James I 1991. The influence of maternal undernutrition in ovine twin pregnancy on fetal growth and Doppler flow-velocity waveforms. Journal of Developmental Physiology 16, 277-282.

Notter DR, Borg RC and Kuehn LA 2005. Adjustment of lamb birth and weaning weights for continuous effects of ewe age. Animal Science 80, 241-248.

Ofir R and Gootwine E 1997. Ovine growth hormone gene duplication-structural and evolutionary implications. Mammalian Genome 8, 770-772.

Okut H, Bromley CM, Van Vleck LD and Snowder GD 1999. Genotypic expression with different ages of dams: III Weight traits of sheep. Journal of Animal Science 77, 2372-2378.

Oliver MH, Breier BH, Gluckman PD and Harding JE 2002. Birth weight rather than maternal nutrition influences glucose tolerance, blood pressure, and IGFI levels in sheep. Pediatric Research 52, 516-524.

Ott TL, Wiley A and Bartol FF 1997. Effects of stage of gestation and uterine ligation on ovine placentome development and glycosaminoglycans. Journal of Animal Science 75, 1053-1062.

Owens JA, Falconer J and Robinson JS 1987. Restriction of placental size in sheep enhances efficiency of placental transfer of antipyrine, 3-0-methyl-Dglucose but not of urea. Journal of Developmental Physiology 9, 457-464.

Pant D, Choi JT, Luther JS, Borowicz PP, Weigl RM, Kirsch JD, Kraft KC, Redmer DA, Reynolds LP and Grazul-Bilska AT 2003. Comparison of gravid uterine parameters in naturally bred ewes and ewes after transfer of in vitro produced embryos, and in single, twin and triplet pregnancies. Journal of Animal Science 81, (suppl. 2) 89, (abstr.).

Parraguez VH, Atlagich M, Diaz R, Bruzzone ME, Behn C and Raggi LA 2005. Effect of hypobaric hypoxia on lamb intrauterine growth: comparison between high- and low-altitude native ewes. Reprodction Fertilility and Development 17, 497-505.

Parraguez VH, Atlagich M, Diaz R, Cepeda R, Gonzalez C, De Los Reyes M, Bruzzone ME, Behn C and Raggi LA 2006. Ovine placenta at high altitudes: Comparison of animals with different times of adaptation to hypoxic environment. Animal Reproduction Science 95, 151-157.

Piper $L R$, Bindon BM and Davis G 1985. The single gene inheritance of the prolificacy of the Booroola Merino. In Genetics of reproduction in sheep (ed. RB Land and DW Robinson), pp. 115-125, Butterworth, London, UK. 
Rae MT, Kyle CE, Miller DW, Hammond AJ, Brooks AN and Rhind SM 2002. The effects of undernutrition, in utero, on reproductive function in adult male and female sheep. Animal Reproduction Science 72, 63-71.

Ranilla MJ, Sulon J, Mantecon AR, Beckers JF and Carro MF 1997. Plasma pregnancy-associated glycoprotein and progesterone concentrations in pregnant Assaf ewes carrying single and twin lambs. Small Ruminants Research 24, 125-131.

Rattray PV, Garrett WN, East NE and Hinman N 1974. Growth, development and composition of the ovine conceptus and mammary gland during pregnancy. Journal of Animal Science 38, 613-626.

Redmer DA, Wallace JM and Reynolds LP 2004. Effect of nutrient intake during pregnancy on fetal and placental growth and vascular development. Domestic Animal Endocrinology 27, 199-217.

Regnault TR, Friedman JE, Wilkening RB, Anthony RV and Hay WW Jr 2005. Fetoplacental transport and utilization of amino acids in IUGR - a review. Placenta 26, suppl. A) S52-S62.

Regnault TR, Galan HL, Parker TA and Anthony RV 2002. Placental development in normal and compromised pregnancies - A Review. Placenta 23, S119-S129.

Reik W and Walter J 2001. Genomic imprinting: parental influence on the genome. Nature Review Genetics 2, 21-32.

Renegar RH, Bazer FW and Roberts RM 1982. Placental transport and distribution of uteroferrin in the fetal pig. Biology of Reproduction 27, 1247-1260.

Revell DK, Main SF, Breier BH, Cottam YH, Hennies M and McCutcheon SN 2000. Metabolic responses to mid-pregnancy shearing that are associated with a selective increase in the birth weight of twin lambs. Domestic Animal Endocrinology 18, 409-422.

Reynolds LP, Borowicz PP, Vonnahme KA, Johnson ML, Grazul-Bilska AT, Redmer DA and Caton JS 2005a. Placental angiogenesis in sheep models of compromised pregnancy. The Journal of Physiology 565, 43-58.

Reynolds LP, Borowicz PP, Vonnahme KA, Johnson ML, Grazul-Bilska AT, Wallace JM, Caton JS and Redmer DA 2005b. Animal models of placental angiogenesis. Placenta 26, 689-708.

Reynolds LP, Caton JS, Redmer DA, Grazul-Bilska AT, Vonnahme KA, Borowicz PP, Luther JS, Wallace JM, Wu G and Spencer TE 2006. Evidence for altered placental blood flow and vascularity in compromised pregnancies. Journal of Physiology 572, 51-58.

Reynolds LP and Redmer DA 2001. Angiogenesis in the placenta. Biology of Reproduction 64, 1033-1040.

Rhind SM, Robinson JJ and McDonald I 1980. Relationship among uterine and placental factors in prolific ewes and their relevance to variations in foetal weight. Animal Production 30, 115-124.

Roberts RM and Bazer FW 1988. The functions of uterine secretions. Journal of Reproduction and Fertility 82, 875-892.

Robinson JJ, McDonald I, Fraser C and Crofts RMJ 1977. Studies on the reproduction in prolific sheep. I. Growth of the products of conception. Journal of Agricultural Science, Cambridge 88, 539-552.

Robinson JS, Kingston EJ, Jones CT and Thorburn GD 1979. Studies on experimental growth retardation in sheep. The effect of removal of a endometrial caruncles on fetal size and metabolism. Journal of Developmental Physiology 1, 379-398.

Robinson OW 1981. The influence of maternal effects on the efficiency of selection; a review. Livestock Production Science 8, 121-137.

Ross MG, Desai M, Guerra C and Wang S 2005. Programmed syndrome of hypernatremic hypertension in ovine twin lambs. American Journal of Obstetrics and Gynecology 192, 1196-1204.

Safari E, Fogarty NM and Gilmour AR 2005. A review of genetic parameter estimates for wool, growth, meat and reproduction traits in sheep. Livestock Production Science 92, 271-289.

Scheaffer AN, Caton JS, Redmer DA and Reynolds LP 2004. The effect of dietary restriction, pregnancy, and fetal type in different ewe types on fetal weight, maternal body weight, and visceral organ mass in ewes. Journal of Animal Science 82, 1826-1838.

Schwartz J and Morrison JL 2005. Impact and mechanisms of fetal physiological programming. American Journal of Physiology-Regulatory, Integrative and Comparative Physiology 288, R11-R15.

Schwartz J and Rose JC 1998. Development of the pituitary adrenal axis in fetal sheep twins. American Journal of Physiology-Regulatory, Integrative and Comparative Physiology 274, R1-R8.
Sinclair KD, McEvoy TG, Carolan C, Maxfield EK, Maltin CA, Young LE, Wilmut I, Robinson JJ and Broadbent PJ 1998. Conceptus growth and development following in vitro culture of ovine embryos in media supplemented with bovine sera. Theriogenology 49, 218.

Smith P, Hudson NL, Corrigan KA, Shaw L, Smith T, Phillips DJ and McNatty KP 1996. Effects of the Booroola gene (FecB) on bodymass, testis development and hormone concentrations during fetal life. Journal of Reproduction and Fertility 108, 253-261.

Smith P, O WS, Hudson NL, Shaw L, Heath DA, Condell L, Phillips DJ and McNatty KP 1993. Effects of the Booroola gene (FecB) on body weight, ovarian development and hormone concentrations during fetal life. Journal of Reproduction and Fertility 98, 41-54.

Snyman MA, Erasmus GJ, van Wyk JB and Olivier JJ 1995. Direct and maternal (co) variance components and heritability estimates for body weight at different ages and fleece traits in Afrino sheep. Livestock Production Science 44, 229-235.

Spencer TE and Bazer FW 2004. Uterine and placental factors regulating conceptus growth in domestic animals. Journal of Animal Science 82 , E4-E13.

Spencer TE, Gray A, Johnson GA, Taylor KM, Gertler A, Gootwine E, Ott TL and Bazer FW 1999. Effects of recombinant ovine interferon tau, placental lactogen, and growth hormone on the ovine uterus. Biology of Reproduction $61,1409-1418$

Spencer TE, Johnson GA, Bazer FW and Burghardt RC 2004. Implantation mechanisms: insights from the sheep. Reproduction 128, 657-668.

Symonds ME, Bryant MJ, Clarke L, Darby CJ and Lomax MA 1992. Effect of maternal cold exposure on brown adipose tissue and thermogenesis in the neonatal lamb. The Journal of Physiology 455, 487-502.

Taylor MJ, Jenkin G, Robinson JS and Thorburn GD 1983. Effect of intrauterine death and fetectomy on ovine placental lactogen production. Research in Veterinary Science 35, 22-24.

Thureen PJ, Trembler KA, Meschia G, Makowski EL and Wilkening RB 1992. Placental glucose transport in heat-induced fetal growth retardation. American Journal of Physiology-Regulatory, Integrative and Comparative Physiology 263, R578-R585.

Tilghman SM 1999. The sins of the fathers and mothers: genomic imprinting in mammalian development. Cell 96, 185-193.

Tosh JJ and Kemp RA 1994. Estimation of variance components for lamb weights in three sheep populations. Journal of Animal Science 72, 1184-1190.

Valinsky A, Shani M and Gootwine E 1990. Restriction fragment length polymorphism in sheep at the growth hormone locus is the result of variation in gene number. Animal Biotechnology 1, 135-144.

Vallet JL, Leymaster KA, Christenson RK, et al. 2002. The influence of uterine function on embryonic and fetal survival. Journal of Animal Science 80, (suppl. 2) E115-E125.

Vandaele L, Verberckmoes S, El Amiri B, Sulon J, Duchateau L, Van Soom A, Beckers JF and de Kruif A 1924. Use of a homologous radioimmunoassay (RIA) to evaluate the effect of maternal and foetal parameters on pregnancyassociated glycoprotein (PAG) concentrations in sheep. Theriogenology 63, 1914-1914.

Vatnick I, Schoknecht PA, Darrigrand R and Bell AW 1991. Growth and metabolism of the placenta after unilateral fetectomy in twin pregnant ewes. Journal of Developmental Physiology 15, 351-356.

Virrenga M, Borowicz PP, Luther JS, Pant D, Redmer DA, Grazul-Bilska AT and Reynolds LP 2004. Vascular development of fetal placental cotyledons (COT) in singles, twin and triplet pregnancies in sheep. Journal of Animal Science 82 , (suppl. 2) 106, abstr.

Vonnahme KA, Hess BW, Hansen TR, McCormick RJ, Rule DC, Moss GE, Murdoch WJ, Nijland MJ, Skinner DC, Nathanielsz PW and Ford SP 2003. Maternal undernutrition from early- to mid-gestation leads to growth retardation, cardiac ventricular hypertrophy, and increased liver weight in the fetal sheep. Biology of Reproduction 69, 133-140.

Wallace JM, Bourke DA, Aitken RP, Milne S and Hay WW 2002. Placental glucose transport in growth restricted pregnancies induced by overnourishing adolescent sheep. Journal of Physiology 547, 85-94.

Wallace JM, Luther JS, Milne JS, Aitken RP, Redmer DA, Reynolds LP and Hay WW Jr 2006. Nutritional Modulation of Adolescent Pregnancy Outcome - A Review. Placenta 27, S61-S68. 
Wallace JM, Milne JS and Aitken RP 2005. The effect of overnourishing singleton-bearing adult ewes on nutrient partitioning to the gravid uterus. The British Journal of Nutrition 94, 533-539.

Ward JW, Forhead AJ, Wooding FB and Fowden AL 2006. Functional significance and cortisol dependence of the gross morphology of ovine placentomes during late gestation. Biolology of Reproduction 74, 137-145.

Wiley AA, Bartol FF and Barron DH 1987. Hystogenesis of the ovine uterus. Journal of Animal Science 64, 1262-1269.

Willard JM, White DR, Wesson CAR, Stellflug J and Sasser RG 1995. Detection of fetal twins in sheep using radioimmunoassay for pregnancy-specific protein B. Journal of Animal Science 73, 960-966.

Wilson AJ, Coltman DW, Pemberton JM, Overall AD, Byrne KA and Kruuk LE 2005. Maternal genetic effects set the potential for evolution in a free-living vertebrate population. Journal of Evolutionary Biology 18, 405-414.
Wilson ME, Biensen NJ, Youngs CR and Ford SP 1998. Development of Meishan and Yorkshire littermate conceptuses in either a Meishan or Yorkshire uterine environment to day 90 of gestation and to term. Biology of Reproduction 58, 905-910.

Wimsatt WA 1950. New histological observations on the placenta of the sheep. The American Journal of Anatomy 87, 391-457.

Winters LM and Feuffel G 1936. Studies on the physiology of reproduction in sheep. IV. Fetal development. Technical Bulletin 118.

Wu G, Wallace JM, Bazer FW and Spencer TE 2006. Intrauterine growth retardation: implications for animal science. Journal of Animal Science 84, 23162337.

Yazdi MH, Engstrom G, Näsholm A, Johansson K, Jorjani $H$ and Liljedahl LE 1997. Genetic parameters for lamb weight at different ages and wool production in Baluchi sheep. Animal Science 65, 247-255. 